\title{
Structure and Functional Analysis of a Tilapia (Oreochromis mossambicus) Growth Hormone Gene: Activation and Repression by Pituitary Transcription Factor Pit-1
}

\author{
BELAID SEKKALI, ${ }^{1, *}$ HASSAN BRIM,${ }^{1, \dagger}$ MARC MULLER,${ }^{1}$ FRANCESCO ARGENTON,${ }^{2}$ \\ MARINO BORTOLUSSI, ${ }^{2}$ LORENZO COLOMBO ${ }^{2}$ ALEXANDRA BELAYEW,${ }^{1, \$}$ \\ and JOSEPH A. MARTIAL ${ }^{1}$
}

\begin{abstract}
A gene encoding the Tilapia mossambica (Oreochromis mossambicus) growth hormone (tiGH) was isolated and sequenced. The gene spans $5.6 \mathrm{~kb}$, including $3.7 \mathrm{~kb}$ of $5^{\prime}$ and $0.2 \mathrm{~kb}$ of $3^{\prime}$ flanking sequences and a 1.7-kb transcription unit comprised of six exons and five introns. The gene and the 5 flanking region contain several potential binding sites for Pit-1, a key transcription activator of mammalian GH genes. One of these $(-57 /-42)$ is highly conserved in fish GH genes. It activates transcription in pituitary cells and binds Pit-1. Transfection of luciferase reporter plasmids containing either the $-3602 /+19$ tiGH sequence or one of its $5^{\prime}$ deletion mutants $(-2863 /,-1292 /$, and $-463 /+19)$ resulted in strong activity in Pit-1-producing rat pituitary GC cells. A dose-dependent activation of the tiGH promoter was achieved in nonpituitary fish EPC and monkey COS cells cotransfected with a rat Pit-1 expression vector, demonstrating the crucial role played by Pit1 as an activator of the $t i G H$ gene. Fusion of the $t i G H$ promoter with the $\beta$-galactosidase gene led to transient expression specifically in the nervous system of microinjected zebrafish embryos. The activity of the $t i G H$ promoter in GC and EPC cells was strongly repressed by extending its $3^{\prime}$ end from +19 to +40 , a sequence in which a Pit-1-binding site was identified using gel retardation assays. Point mutations of the site that suppressed Pit-1 binding in vitro restored full tiGH promoter activity. Thus, a Pit-1-binding site located in the $5^{\prime}$ untranslated region mediates Pit-1-dependent repression of the tiGH gene.
\end{abstract}

\section{INTRODUCTION}

$\mathbf{P}$ ITUITARY GROWTH HORMONE $(\mathrm{GH})$ is a single-chain polypeptide of about $22 \mathrm{kDa}$ that is essential for normal growth and development of all vertebrates (Holly and Wass, 1989). In salmonids, GH participates together with thyroid hormone in seawater adaptation, which involves enhanced growth, body silvering, and tolerance to increased osmolarity (Barron, 1986; Miwa and Inui, 1985; Bolton et al., 1987; Sweeting and McKeown, 1987). With prolactin (Prl), placental lactogen, and somatolactin, GH constitutes a family of structurally and functionally related proteins believed to have a common ancestral origin (Moore et al., 1982; Miller and Eberhardt, 1983; RandWeaver et al., 1992). Thus, they can provide an ideal model system for investigating the structure-function relations, evolution, and regulation of gene expression.

Growth hormone has been studied extensively at the levels of protein, mRNA, and genomic sequences in a variety of species. The nucleotide sequence of GH genes has been determined from birds (Tanaka et al., 1992), mammals (Barta et al., 1981; DeNoto et al., 1981; Gordon et al., 1983; Byrne et al., 1987; Vize and Wells, 1987), and fishes (Agellon et al., 1988; Johansen et al., 1989; Chiou et al., 1990; Ber and Daniel, 1992; Zhu et al., 1992; Devlin, 1993; Du et al., 1993; Tang et al.,

\footnotetext{
${ }^{1}$ Laboratoire de Biologie Moléculaire et de Génie Génétique, Université de Liège, Institut de Chimie B6, B-4000 Sart-Tilman, Belgium.

${ }^{2}$ Dipartimento di Biologia, Università di Padova, Via U. Bassi 58/B, I-35121 Padova, Italy.

*Present address: National Institute of Medical Research, Division of Molecular Immunology, The Ridgeway, Mill Hill, London NW7 1AA, UK.

$\dagger$ Present address: V.I.T.O., Boeretang 200, B-2400 Mol, Belgium.

\$Present address: Center for Molecular and Vascular Biology, Katholieke Universiteit Leuven, Gasthuisberg, Herestraat 49, 3000 Leuven, Belgium.
} 
1993; Yowe and Epping, 1995). The primary transcript ranges from $1631 \mathrm{nt}$ to $4166 \mathrm{nt}$ in length. Known bird and mammalian $\mathrm{GH}$ genes consist of five exons, whereas fish GH genes contain either five or six exons.

In vertebrates, the somatotroph cells of the anterior pituitary gland constitute the major site of $\mathrm{GH}$ expression, suggesting that the developmental mechanisms determining tissue-specific expression of the genes have been conserved in the course of evolution. In mammals, transcription of the $\mathrm{GH}$ gene requires the interaction of the regulatory factor Pit-1, also called growth hormone factor 1 (GHF-1), with two cis-acting elements within the proximal promoter (review ed in Theill and Karin, 1993; Andersen and Rosenfeld, 1994). This transcriptional factor, a POU homeodomain protein (Gehring et al., 1994), is also essential for the expression of several other genes, including Prl (Mangalam et al., 1989). Recently, a Pit-1 cDNA has been cloned from rainbow trout, and the functional binding of this fish Pit1 to the trout GH promoter has been demonstrated by DNase I footprinting (Yamada et al., 1993). Furthermore, expression of a chimeric rat Pit-1 containing the salmon Pit-1 POU domain was shown to be effective in trans-activating the chinook salmon Prl gene (Elsholtz et al., 1992), suggesting that both the structure and the function of Pit-1 were highly conserved during vertebrate evolution.

We cloned, sequenced, and characterized the genomic structure of the Tilapia mossambica (Oreochromis mossambicus) $\mathrm{GH}(t i G H)$ gene. By transfection and cotransfection experiments, we showed that the $t i G H$ promoter is pituitary specific and that this specificity is attributable to Pit-1. Microinjection into zebrafish embryos leads to activation of the $t i G H$ promoter in the developing nervous system. In addition, we showed that a Pit-1-binding site in the $5^{\prime}$-untranslated region (UTR) leads to Pit-1 repression of the $t i G H$ promoter.

\section{MATERIALS AND METHODS}

\section{Library screening}

The 400,000 plaques (recombinant Lambda GEM 11) of a genomic library from tilapia (Sweenen et al., 1992) were screened using as a probe the $t i G H$ cDNA (Rentier-Delrue et $a l ., 1989$ ) labeled by random priming (Random Priming DNA Labeling Kit; Boehringer Mannheim, Germany) with $\left[\alpha-{ }^{32} \mathrm{P}\right]$ dCTP (3000 Ci/mM; Amersham). Hybridization and washing were carried out under stringent conditions. Positive clones were purified by three additional screening cycles. After amplification (Grossberger, 1987), DNA was prepared and purified on a Quiagen ion-exchange column (Diagen, Hilden, Germany) according to the manufacturer's instructions. Restriction mapping and Southern blotting were performed using standard procedures (Sambrook et al., 1989).

\section{Plasmid constructs}

The two contiguous $S a c$ I fragments $(4.5 \mathrm{~kb}$ and $3.5 \mathrm{~kb})$ revealed by Southern blotting in the $t i G H$ recombinant phage were subcloned into the $S a c$ I site of the pGEM $3 \mathrm{Z}(+)$ vector, yielding pGEM4.5tiGH and pGEM3.5tiGH. The p0-Luc plasmid was prepared from the promoterless plasmid pBL-CAT6 (Boshart et al., 1992) by replacement of the chloramphenico 1 acetyltransferase (CAT) gene with the luciferase (Luc) coding region from pXP2 (Nordeen, 1988). The pCMV-Luc plasmid has been described previously (Sekkali et al., 1994). The pCMV- $\beta$ Gal (MacGregor and Caskey, 1989) contains the $E$. coli $\beta$-galactosidase reporter gene under the control of the cytomegalovirus promoter/enhancer. The expression vector containing the Rous sarcoma virus (RSV) promoter/enhancer directing expression of the rat Pit-1 has been described (Bodner et al., 1988).

The $p(-463 /+19)$ tiGH-Luc and $p(-463 /+40)$ tiGh-Luc plasmids contain 463 bp of the tilapia $\mathrm{GH} 5^{\prime}$ flanking region and, respectively, 19 and $40 \mathrm{bp}$ of the transcribed sequence fused to the luciferase gene. The plasmids were prepared by polymerase chain reaction (PCR) amplification of pGEM4.5tiGH using the $5^{\prime}$ primer p-463 (5'-TTTCAGAATTCAGTTTAATGAC- $\left.3^{\prime}\right)$ and either $\mathrm{p}+19$ (5'-GTGAGTCGGTGGTTCTGA-3') or p+40 (5'-TGCGGCTCAGATGATTATG-3') as a $3^{\prime}$ primer. The amplified fragments were cloned by bluntend ligation into the $B g / \mathrm{II}$ site of p0-Luc. The tiGH-Luc junctions were confirmed by DNA sequencing (Sanger et al., 1977).

The BglII (-1292/-206) fragment of the tiGH 5' flanking region was cloned into the $B a m H I / B g l \mathrm{II}$ sites of the $\mathrm{p}(-463 /+19)$ tiGH-Luc expression vector, yielding $\mathrm{p}(-1292 /$ +19)tiGH-Luc. Similarly, the PstI/SalI (-3602/-474) fragment was inserted into the PstI/SalI sites of the $\mathrm{p}(-1292 /$ +19)tiGH-Luc expression vector, yielding $\mathrm{p}(-3602 /+19)$ tiGH-Luc. The $\mathrm{p}(-2863 /+19) \mathrm{tiGH}-\mathrm{Luc}$ expression vector was constructed by HindIII digestion and religation of the $\mathrm{p}(-3602 /+19)$ tiGH-Luc. Plasmid p0-LacZ was constructed by inserting the $X b a \mathrm{I}$ fragment from $\mathrm{pCMV} \beta \mathrm{Gal}$, containing the LacZ gene, into pGEM3 (Promega). The p $(-463 /+19)$ tiGH LacZ vector was obtained by replacing the luciferase coding region (XhoI/KpnI fragment) from $\mathrm{p}(-463 /+19)$ tiGH-luc with the $X h o \mathrm{I} / K p n \mathrm{I}$ fragment from $\mathrm{p} 0$-LacZ containing the LacZ coding sequence. The pTk-Luc (Poncelet et al., 1996) contains the luciferase reporter gene fused to the herpes simplex thymidine kinase (Tk) promoter. The p2xtiGHF1-Tk-Luc was constructed by cloning the tiGHF1 double-stranded synthetic oligonucleotide (see the sequence below) into the BamHI site of the pTk-Luc vector. The structure of all of the constructs was confirmed by restriction mapping. All these plasmids were prepared by alkaline lysis and purified by a double centrifugation in $\mathrm{CsCl}$ /ethidium bromide gradients (Sambrook et al., 1989).

\section{Cell culture and transfection experiments}

The GC cells were derived from a rat pituitary tumor and express the endogenous GH gene (Tashjian et al., 1968). This cell line was grown as monolayers at $37^{\circ} \mathrm{C}$ in Ham's F12 nutrient mixture supplemented with $10 \%$ fetal bovine serum (FBS) and $1 \%$ penicillin-streptomycin. The EPC cells (Epithelioma papulosum cyprini), derived from carp epidermal herpes virusinduced hyperplastic lesions (Fijan et al., 1983), were grown at $28^{\circ} \mathrm{C}$ in Dulbecco's Minimal Essential Medium supplemented with $10 \%$ FBS and $1 \%$ penicillin-streptom ycin. The COS-7 cells, derived from simian kidney, were grown at $37^{\circ} \mathrm{C}$ in the same medium as the EPC cells. Neither COS-7 nor EPC cells express endogenous $\mathrm{GH}$ gene.

For transfection assays, cells were harvested using trypsinEDTA and resuspended in the same culture medium at a con- 
centration of $15 \times 10^{6}$ cells $/ \mathrm{ml}\left(12 \times 10^{6} / 800 \mu \mathrm{l}\right)$. They were mixed with 4 pmoles of purified plasmid DNA and transfected by electroporation in 4-mm cuvettes using a single pulse (GC: $275 \mathrm{~V}, 1500 \mu \mathrm{f}$; EPC and COS: $250 \mathrm{~V}, 1500 \mu \mathrm{F}$ ) delivered by a Cellject apparatus (Eurogentec, Seraing, Belgium). The transfected cells were immediately transferred to three tissue culture dishes $(35 \mathrm{~mm})$ and maintained in the same culture medium. After $48 \mathrm{~h}$, cells were harvested by scraping, washed three times in cold $10 \mathrm{mM}$ phosphate-buffere $\mathrm{d}$ saline, and resuspended in $200 \mu \mathrm{l}$ of luciferase buffer ( $25 \mathrm{mM}$ potassium phosphate, $\mathrm{pH}$ 7.8; $8 \mathrm{mM} \mathrm{MgCl}_{2}, 1 \mathrm{mM}$ EDTA, $1 \% \mathrm{BSA}, 15 \%$ glycerol, and $1 \mathrm{mM}$ DTT). After three cycles of freeze-thawing, the suspension was centrifuged, and the luciferase and $\beta$-galactosidase assays were performed. For the cotransfection experiments, EPC and COS cells were transfected using the calcium phosphate precipitation procedure as described by Inoue et al., (1990).

\section{Luciferase and $\beta$-galactosidase assays}

A total of $100 \mu 1$ of cell extract was mixed with $80 \mu 1$ of luciferase buffer. The tubes were placed in a Lumat LB 951 luminometer (EG G. Berthold, Belgium), and the reaction was initiated by injecting $100 \mu \mathrm{l}$ of $0.3 \mathrm{mM}$ luciferin and $0.8 \mathrm{mM}$ ATP. The peak light emission was recorded for $20 \mathrm{~s}$. The $\beta$ galactosidase activity was determined using $50 \mu$ of extract as described (Sambrook et al., 1989).

\section{Zebrafish egg microinjection and $\beta$-galactosidase assay}

All solutions for microinjection were prepared by diluting a preparation of plasmid DNA (in $10 \mathrm{mM}$ Tris $\mathrm{HCl}[\mathrm{pH} 8.0]$ and $1 \mathrm{mM}$ EDTA) to a final concentration of $40 \mathrm{ng} / \mu \mathrm{l}$ in $10 \mathrm{mM}$ phosphate buffer $\mathrm{pH} 7.4,150 \mathrm{mM} \mathrm{NaCl}$, and $0.25 \%$ phenol red to monitor the injection. Fertilized zebrafish eggs at the 1- to 2-cell stage were injected as described (Argenton et al., 1996a) under a standard binocular microscope and incubated for $24 \mathrm{~h}$ at $28.5^{\circ} \mathrm{C}$. For tissue localization, embryos injected with the $\beta$ galactosidase reporter plasmid, $\mathrm{p}(-463 /+19) \mathrm{tiGH}-\beta$ gal, were stained in situ for $\beta$-galactosidase activity as described (Westerfield et al., 1992) except that the concentrations of $\mathrm{K}_{4}\left[\mathrm{Fe}_{3}(\mathrm{CN})_{6}\right)$ and $\mathrm{K}_{3}\left[\mathrm{Fe}_{2}(\mathrm{CN})_{6}\right)$ were $5 \mathrm{mM}$, the concentration of X-Gal (5-bromo-4-chlo ro-3-indolyl- $\beta$-D-galactoside) was $0.2 \%$, and the embryos were stained for 16 to $24 \mathrm{~h}$.

\section{Extract preparation}

Nuclear extracts from GC cells and tilapia and trout pituitaries were prepared as described (Dignam et al., 1983). The protein concentration in these extracts was determined using the Bradford assay (1976) using BSA as a standard.

\section{Oligonucleotides}

The synthetic oligonucleotides were obtained from Eurogentec. The hGHF1 and tiGHF0 oligonucleotides contain, respectively, the proximal Pit-1 binding site of the human GH promoter (Lefevre et al., 1987) and the 5' untranslated Pit-1binding site of the $t i G H$ gene. The tiGHF0m oligonucleotide corresponds to the tiGHF0 oligonucleotide with a mutation in the consensus Pit-1-binding site. The AP-1 oligonucleotide contains the AP-1 site of the human collagenase promoter (Angel et al., 1987). For each oligonucleotide, the sequence of one strand is presented below:

\section{hGHF1 5'-GATCCCATGCATAAATGTACACAG-3' \\ tiGHF1 5'-T TCTCCTGATGAATTTAA ACATC- TAGTTTTCA-3' \\ tiGHF0 5'-CCACCG ACTCACA TCA T A A TCA TCT - GAGCCGCA-3' \\ tiGHF0m 5'-CCACCGACTCACA TCAT T GAGCCGCA-3' \\ AP-1 5'-AGCTTAAAGCATGAGTCAGACACCT-3' \\ tiP1 5'-GATCCAGTCACCCTGCTCCTGCATAAC- CAAACGACTGGAGG-3' \\ Sp1 5'-CGACTGATCAGTTCCGCCCATTCTCCGC- CCCAG \\ DR-4 5' -TCGA A GCT TCAGGTCACAGGAGGT - CAAGCT-3'}

\section{Electrophoretic mobility shift assay}

The synthetic double-stranded oligonucleotides (hGHF1 and tiGHF0) were end-labeled using $\left[\gamma_{-}{ }^{32} \mathrm{P}\right]$-ATP and T4 polynucleotide kinase. Electrophoretic mobility shift assays (EMSA) were performed using $3 \mu \mathrm{g}$ of GC cell or $15 \mu \mathrm{g}$ of tilapia or trout pituitary nuclear extract, $2 \mu \mathrm{g}$ of poly(dI-dC), and 5000 to $10,000 \mathrm{cpm}$ of ${ }^{32} \mathrm{P}$-labeled oligonucleotides in $20 \mathrm{mM}$ Tris $\mathrm{HCl} \mathrm{pH} 7.9,5 \mathrm{mM} \mathrm{MgCl} 2,100 \mathrm{mM} \mathrm{KCl}, 0.1 \mathrm{mM}$ EDTA, $7.5 \%$

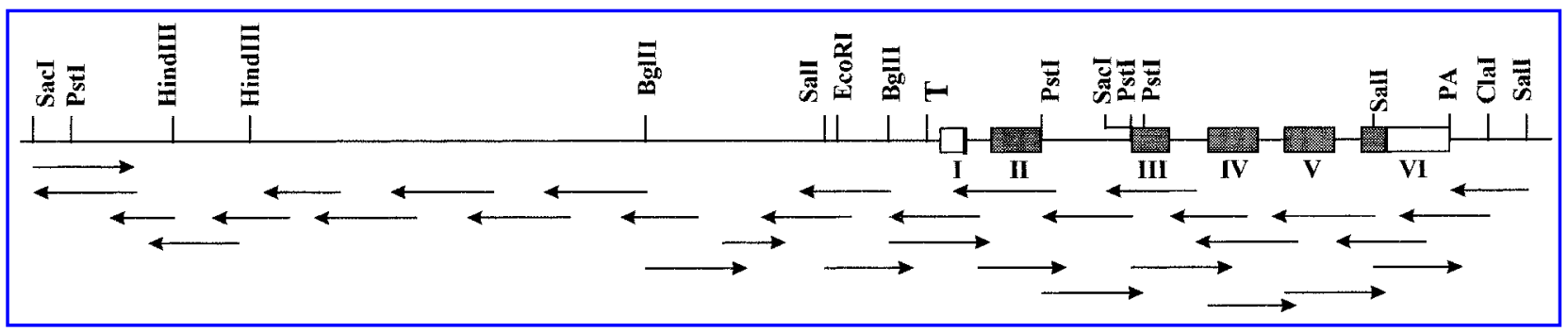

FIG. 1. Restriction map and DNA sequencing strategy for the SacI fragments of the tilapia mossambica GH recombinant clone. Arrows indicate the direction of sequencing by the chain-termination method. T represents the TATA box, and PA represents the polyadenylation signal. Open boxes indicate transcribed and untranslated regions, and hatched boxes indicate the coding regions. Thin lines represent introns and flanking sequences. 
gagctccttcagtgacagactgctgcatcctcgatgcatgaaggagcaaaccgcaggtccttcctccctgc agctgtcagactgtacaatcagaactgctcccaacaatcatagatgttacatctgcgctgtaactcgaata agttaatcaaccgatttgcactacaacctggtttacctcttatctgtagttatttatattaatttaataa ctgtacagtactctgtttatagtaaccattgtccttaatgtaaatatgtaagaaaattgtgtatgtttct gttctgtgtcctgtgtactgtgtttgtttgtatatgtgtcttttctggctgctgttaaaacaaattccc cttgtgggacaattaaggattattctattctattcctattctaaagcgcgtcacagagtcgttcatgatc acaatggcatcctgagggtgtctgccaatgaatgaatcatcctcattaactaa caaatcacaatgctgta agggtaacactgctgactttagactttagtccaggacataacaaagcttatcagtatcagcaggaactat ggattgaacgtagcacacataattttactttctggttttaatttgaacaccacactgtaaatctaattg gttcaaagaactcaaaaaaactatgcaaactgttggccctcaaaaacttgagtaaagttttacttaagatt $\underset{\text { ctatgcaaacttgttgtctcaaaaacttgagtaaagcttacttaagatgactgttaggacaacttattca }}{\longrightarrow}$ ttgcagtatgcactattaagaataactgatattctgactgtacaatactaattgtttacctactgacaaac atttcaaatttaactaaatgaaaaacaaattgtggtaacctgaatatgattaaaataattaacgacact ttttgtaatgatgttaaatcagcccaactttatttcaaattcaaaactataacagccaacatactga cactgttctgccgaacaacaa caattatattgccatcactgtataatcttacaatgaaacaagtctcag atttaattattctgaaataagtttaggtctaccacaagttgtttagtgcttacattacttatataatca cacaggagctggaatgttgtaatattttagatgcttgtttccagtccagcattactgcctgaatgactgt cattgattgaggtgatccaaatgtaagtgcagaagaaagtctttaacttcccttgtcctgtaagcaaacaa tcatatttttggaaaccatgaacttaattgctttcttaaacatttttctgcatttggtatagaacagac tccaatttagacgatctcaggctccctccccaccggagaggtgacattcaatgtcccaaattgtcagtctg gatagccctgaccaccacccaacatacalaatgtcatgaagoatcattttaaaagggcctatgtcaaa catgcatactttcattctaatgatgtgcaatttgattggaacaaacaaatgttgctgttagaaaacttgc agacttcactatatacagtgtagaccctctaaactaagtttggggatgtgatctttcaagaaatgcagacc aactgttgttgtttgtttacttacacagcatgtcttgtagaattaactgtggtcaccagcaacagcatag tgcagtcatatctaaagtctaataacagaagacaggaaaagatcagtaaagaacaacttccccaaccaa aacacaa taaa caataagtaaa cagggtggatctaaagtatggttaaagttcagcctgattaatataa atgtcactgacagttgctaacatattggaaacccaaacacttactgatgtctttctgtccaacagcagg agtgctggtcccgagcctcaaagacagtaagaagcaagcagagggagaaaaacagaacatttttttagaa gcagatttgatccttaatggctgtgcaatcattataacttacaacacaggtcaatgtagaccccatacaac caattagactaacacatatagtattaaaacaccatctactactgtgtctgaatgtgtggtattggcact gtcagtttaggcctgaagagatatgtgtttaaaaagaccacctaatttaaatataatcattacatacttg ttaaagttaacttccaatatataagtttctaataagcaaatgaccagatctaacatgtggcagggttt atatgtaacataaatgttttctttatgattcaactgtggaatttaacttaattctttagaaggacaagcta gctttcacaacaaacctttttttaaacacatttttaaccaaataatactattgttattattattatt attattatttaaatataataaacagaaagtggttaaatataaagcagttcgccttatgttgttaat aagggctagatttgagattaatagatgccccagatgttcaaaagctgccacaaagcattaaaaaatagac gtctccgaaacgtcggagcatttttgcaalatgtgtgtcttgataaatcgagcagatatttgaacttta cacagctacattctcgcctgaaatatcttaaacgttattttgtgacccagaaaaagtaatatttaaaagtt tttttagccggctcctccgccattgccgcgcttacaagtacgcacaggctctagcaaccgcggcgacaaat gcgatcctcctccttttccccagactaccctttctgggtcacaaaataacctttaagatatttcaggat gtgtccatggctaggcgcagtgtgatatgacacctgaggaatagaataagtatggggagaaggaaccttga attatgaaatagctgcactttaaatgtaagtttcattaaagtgttttcaggtccaactgataagcatgaa tgttaaattgtgtcgaccttatttcagaattcagtttaatgactgaatgttctgtcaacaaaggtgatt gtgagtcatcaaagcgagcactactgtctgtcaccatgaaacctgaacacatgtcaaactgtcggtgtga acatttctgtcccaactcattcgtgagcatgtgcgttcaaagtgacttctctgtggatgaaagctcgaata aaatcttttcacctgaaaatttgatttgatgtaaatattttggagttttaaaaactttacattagatct ccttttaaatgttaacaaacatgttggatgtcagagcactttagtcaccagcggtgtgtttttcatgtagc
atcaatatgatgattgaggtgttaatgttaattagacttagacacacgtgtttgctcatgtaacgtttctc $+1$

-56 ctgatgaatttaaacatctagttttcaactataaaagcaaaaactctgagctgaaaacATCAGAACCACCG

FIG. 2. (Continued on next page) The complete nucleotide sequence of the tilapia mossambica growth hormone gene. Exons are shown in uppercase letters; introns and flanking regions are in lowercase letters. The TATA box and the poly(A) signal are in boldface and underlined. The numbering is shown in the left margin and refers to the last nucleotide on the corresponding line. The tsp is located at nucleotide +1 , as assigned by analogy with the $t G H 2$ gene of tilapia nilotica (Ber and Daniel, 1992). Encoded amino acid residues, represented by one-letter code, are placed above the first nucleotide of each codon. The inverted repeat and the direct repeat observed in $t i G H$ are represented by arrows and in boldface. Potential Pit-1-binding sites are represented in boldface. The tiGHF0 site is indicated. The sequence is available in the EMBL nucleotide sequence database under Accession Number Y11732. 
14 ACTCA ATCATAATCATCTGAGCCGCAAACAGAGCCTGAACTGATGCCAGCCATG AAC TCA G gtaag

81 aatctgggctcCCCCacgagaagggaccactgctttatgatatttaacaaagtctgaaactgtctgtctgt

$$
\begin{array}{llllllllllll}
V & I & I & I & S & V & V & C & L & G & V & S
\end{array}
$$

152 ctgtctgtctgtctgtcag TC GTC CTC CTG CTG TCG GTT GTG TGT TTG GGC GTC TCC $\begin{array}{llllllllllllllllll}S & Q & Q & I & T & D & S & Q & R & I & F & S & I & A & V & N & R & V\end{array}$

209 TCT CAG CAG ATC ACA GAC AGC CAG CGT TTG TTC TCC ATT GCA GTC AAC AGA GTC $\begin{array}{llllllllllllll}\boldsymbol{T} & \boldsymbol{H} & \boldsymbol{L} & \boldsymbol{H} & \boldsymbol{L} & \boldsymbol{L} & \boldsymbol{A} & \boldsymbol{Q} & \boldsymbol{R} & \boldsymbol{L} & \boldsymbol{F} & \boldsymbol{S} & \boldsymbol{D} & \boldsymbol{F}\end{array}$

262 ACG CAC CTG CAC CTG CTC GCC CAG AGA CTC TTC TCG GAC TTT gtaagcetgcagcag

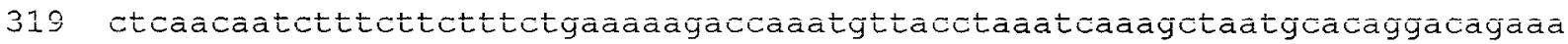
390 ctaggttcaaatacgttcaacaaatgttctggatattcagtgtgtgcagtgagtttcgatgcacacaga 461 catatggacacatttcacatttgatgtcaagggaaccgagacactttgtagactgtcactgctaaaacac 532 agcagatgtttacactttacattttagtgacagtcagctataatctcaggatattcagttaagaattatga

603 aacgatattaaatttgctgtcagtcaataaacacaggtgttcctgtgtattttgtgtatttctgtatgc

674 aaccttgtattttgtgtgttaccattctttaattctacacatgtcatag GAG AGC TCT CTG CAG $\begin{array}{llllllllllllllllll}\boldsymbol{T} & \boldsymbol{E} & \boldsymbol{E} & \boldsymbol{Q} & \boldsymbol{R} & \boldsymbol{Q} & \boldsymbol{L} & \boldsymbol{N} & \boldsymbol{K} & \boldsymbol{I} & \boldsymbol{F} & \boldsymbol{L} & \boldsymbol{Q} & \boldsymbol{D} & \boldsymbol{F} & \boldsymbol{C} & \boldsymbol{N} & \boldsymbol{S}\end{array}$ 740 ACG GAG GAG CAA CGT CAG CTC AAC AAA ATC TTC CTG CAG GAC TTC TGC AAC TCT $\begin{array}{llllllllllllllll}D & Y & I & I & S & P & I & D & K & H & \boldsymbol{E} & \boldsymbol{T} & \boldsymbol{Q} & \boldsymbol{R} & \boldsymbol{S} & \boldsymbol{S}\end{array}$

792 GAT TAC ATC ATC AGC CCG ATC GAC AAA CAC GAG ACG CAG CGC AGC TCG gtcatta

863 aactacacagtactacgcaacactgcacagcagtacacagtactacacagtaccagaggtactctgcccat

926 gcgataatcttctgaagctgttgtctgcttattgatgggtcacag GTC CTG AAG CTG CTG TCG $\begin{array}{llllllllllllllllll}I & S & Y & G & L & V & E & S & W & E & F & P & S & R & S & I & S & G\end{array}$

980 ATC TCC TAT GGA CTG GTT GAG TCC TGG GAG TTT CCC AGC CGC TCT CTG TCT GGA $\begin{array}{lllllllllllllllllll} & \boldsymbol{G} & \boldsymbol{S} & \boldsymbol{S} & \boldsymbol{L} & \boldsymbol{R} & \boldsymbol{N} & \boldsymbol{Q} & \boldsymbol{I} & \boldsymbol{S} & \boldsymbol{P} & \boldsymbol{R} & \boldsymbol{L} & \boldsymbol{S} & \boldsymbol{E} & \boldsymbol{L} & \boldsymbol{K} & \boldsymbol{T} & \boldsymbol{G} \\ 1034 & \text { GGT } & \text { TCC } & \text { TCT } & \text { CTG } & \text { AGG } & \text { AAC } & \text { CAG } & \text { ATT } & \text { TCA } & \text { CCA } & \text { AGG } & \text { CTG } & \text { TCT } & \text { GAG } & \text { CTT } & \text { AAA } & \text { ACG } & \text { GGA }\end{array}$ $\begin{array}{llllll}I & I & I & \boldsymbol{I} & \boldsymbol{I} & \boldsymbol{R}\end{array}$

1088 ATC TTG CTG CTG ATC AGGgtgagaagataaattgcacaaacatattgctccatgcatggtaccaat $\begin{array}{llllllllllll}\boldsymbol{A} & N & \boldsymbol{Q} & \boldsymbol{D} & \boldsymbol{E} & \boldsymbol{A} & \boldsymbol{E} & \boldsymbol{N} & Y & \boldsymbol{P} & \boldsymbol{D} & T\end{array}$

1154 gcgactaaccacctgactctacagGCC AAT CAG GAT GAA GCA GAG AAT TAT CCT GAC ACC $\begin{array}{llllllllllllllllll}D & \boldsymbol{T} & \boldsymbol{L} & \boldsymbol{Q} & \boldsymbol{H} & \boldsymbol{A} & \boldsymbol{P} & \boldsymbol{Y} & \boldsymbol{G} & \boldsymbol{N} & \boldsymbol{Y} & \boldsymbol{Y} & \boldsymbol{Q} & \boldsymbol{S} & \boldsymbol{L} & \boldsymbol{G} & \boldsymbol{G} & \boldsymbol{N}\end{array}$

1214 GAC ACC CTC CAG CAC GCT CCT TAC GGA AAC TAT TAT CAA AGT CTG GGA GGC AAC $\begin{array}{llllllllllllllllll}E & S & L & \boldsymbol{R} & \boldsymbol{Q} & \boldsymbol{T} & \boldsymbol{Y} & \boldsymbol{E} & \boldsymbol{L} & \boldsymbol{L} & \boldsymbol{A} & \boldsymbol{C} & \boldsymbol{F} & \boldsymbol{K} & \boldsymbol{K} & \boldsymbol{D} & \boldsymbol{M} & \boldsymbol{H}\end{array}$

1268 GAA TCG CTG AGA CAA ACT TAT GAA TTG CTG GCT TGC TTC AAG AAG GAC ATG CAC $K$

1322 AAG gtgaggtagtggataatggtgatgtcactgtgatgatgacaatgatgtaatgatggtgaagatgaca

1392 tttttgttgcagGTG GAG ACC TAC CTG ACG GTA GCT AAA TGT CGA CTC TCT CCG GAA $\begin{array}{lllll}A \quad \boldsymbol{N} & \boldsymbol{C} & \boldsymbol{T} & \boldsymbol{I} & \boldsymbol{A} M\end{array}$

1450 GCA AAC TGC ACT CTG TAG CTCCACCTAATATTGATACTGATACGTGCTCTGTAGCCCCACCCTCA 1515 TGTTGGCAAACTCTGCTPACATGTGTTAGCATTAGCAATAGGATAATAATACGAGTGGTAATCGTGACATC 1586 AGAAGTTTTTCTGACATAACTGTGATCGAAGGTGTGAACGGGAATAATGTTATTCTGTGAAATAAATGTGT

1657 TGCATTGatgtgtggagtctgttctttctgatttatttggagaatttattctctatcctgtgacttcttac 1728 acagaaacacatgctgacgtgagctgaggtccatatcgattggcagaaaactgactcgaacatgtcagct 1801 tagaatgatcctcttatggtcctctgacagtggactcgtctctgtgcttgtcctgctagacctcagtgca 1872 gcgttcaatactgtcgacc

FIG. 2. (Continued)

glycerol, and $1 \mathrm{mM}$ dithiothreitol. The resulting DNA-protein complexes were resolved by electrophoresis on a prerun $5 \%$ polyacrylamide gel using $0.5 \times \mathrm{TBE}$ as running buffer. In competition experiments, we used a 100 - or 200 -fold molar excess of unlabeled double-stranded oligonucleotides. For supershift assays, a rabbit polyclonal IgG against the $\mathrm{N}$-terminal part (aa 1-157) of bacterially expressed human Pit-1 (Pernasetti et al., 1998) was used. The GC nuclear extract ( $3 \mu \mathrm{g})$ was incubated for $1 \mathrm{~h}$ at $4^{\circ} \mathrm{C}$ with $1 \mu \mathrm{l}$ of crude antiserum. Then, $0.5 \mathrm{ng}$ of ${ }^{32} \mathrm{P}$-labeled oligonucleotide was added for $30 \mathrm{~min}$ at $4{ }^{\circ} \mathrm{C}$. The samples were loaded on a $5 \%$ polyacrylamide gel and run in $0.5 \times$ TBE buffer.

\section{RESULTS}

Isolation, molecular cloning, and sequencing of genomic clones

Screening of a genomic library from Oreochromis mossambicus using the $t i G H$ cDNA as a probe yielded 10 purified re- 
combinant phage. After restriction mapping and Southern blot analysis (data not shown), it appeared that these clones were identical and comprised two contiguous SacI fragments (4.5 and $3.5 \mathrm{~kb}$ ) hybridizing with the probe. These fragments were introduced into the pGEM vector and used to generate a library of partial deletion subclones and sequenced using a bidirectional strategy (Fig. 1).

\section{Primary structure of tiGH}

The two contiguous $\mathrm{Sac}$ I fragments contained the whole coding region of the $t i G H$ gene and about $3.7 \mathrm{~kb}$ of $5^{\prime}$ flanking region. Alignment of the $t i G H$ genomic sequence with a cDNA encoding the GH from another tilapia species (Oreochromis niloticus) (Rentier-Delrue et al., 1989) identified six exons and five introns (Fig. 2). This general structure is similar to that of the GH genes from rainbow trout (Agellon et al., 1988), Atlantic salmon (Johansen et al., 1989; Male et al., 1992), tilapia nilotica (Ber and Daniel, 1992, 1993) and the perciforme barramundi (Lates calcarifer) (Yowe and Epping, 1995), which have an extra intron compared with mammalian, chicken, and carp GH genes. All five introns start with a GT and end with an AG dinucleotide, in agreement with the classical consensus splice sites (Mount, 1982).

The transcription start point (tsp) was assigned by sequence alignment with the tilapia nilotica GH genes (Ber and Daniel, 1992, 1993). This tsp most likely is functional, as the adenine residue is the central base of a $\mathrm{CA}(\mathrm{C} / \mathrm{T})$ motif, shown to be essential for eukaryotic gene tsp (Bucher, 1990). No other $\mathrm{CA}(\mathrm{C} / \mathrm{T})$ triplet was found between the TATA box and this tsp (Fig. 2). From comparison with the structural part of the two $\mathrm{GH}$ genes identified in tilapia nilotica ( $\mathrm{tGH} 1$ and $\mathrm{tGH} 2$; Ber and Daniel, 1992, 1993), the primary transcript encoded by the $t i G H$ gene seems to be identical to the $t G H 2$ gene. Indeed, only three substitutions and one insertion are observed between the primary transcript of $t i G H$ and $t G H 2$. Two of the substitutions are located in the second intron, and the third one is located in the $3^{\prime}$-UTR. The primary transcript encoded by the $t i G H$ gene is $1666 \mathrm{nt}$ long, which is $4 \mathrm{nt}$ longer than the primary transcript of $t G H 2$. The length difference results from the insertion of an additional CTGT repeat in the first intron (7 in $t i G H$ and 6 in $t G H 2$ ).

\section{Analysis of $3^{\prime}$ and $5^{\prime}$ flanking sequences of tiGH}

At the $3^{\prime}$ end, a putative polyadenylation signal, AATAAA (Fig. 2) (Proudfoot and Brownlee, 1976), is located 178 bp downstream from the stop codon. It is identical to the poly(A) signal found in salmon, barramundi, chick, and mammals but differs from the carp poly(A) signal, ATTAAA. In addition, the length of the $t i G H 3^{\prime}$-UTR is substantially the same as in mammal, chicken, and barramundi GH genes (100-180 bp) (Miller et al., 1980; Tanaka et al., 1992; Barta et al., 1981; DeNoto et al., 1981; Gordon et al., 1983; Byrne et al., 1987; Vize and Wells, 1987; Yowe and Epping, 1995) in contrast to 500 bp in other fishes (Agellon et al., 1988; Johansen et al., 1989; Chiou et al., 1990; Ber and Daniel, 1992; Zhu et al., 1992; Devlin, 1993; Du et al., 1993; Tang et al., 1993). The 5' flanking region of the $t i G H$ gene contains the sequence TATAAA at a distance of $23 \mathrm{nt}$ upstream from the transcription start point. Analysis of the $3.7-\mathrm{kb}$ sequence $5^{\prime}$ upstream from the tsp of tiGH reveals that only this putative TATA box is $100 \%$ conserved in all the known GH genes.

As it was known that the pituitary-specific transcription of the GH gene depends on the specific interaction of the nuclear trans-acting protein GHF-1/Pit-1 (Bodner and Karin, 1987; Nelson et al., 1988) with cis-acting elements located in the promoter, a close search for possible Pit-1-binding sites within the $t i G H$ gene was carried out in the $5^{\prime}$ flanking region. We found several putative binding sequences for Pit-1 differing by no more than 1 or $2 \mathrm{nt}$ from the consensus $5^{\prime}-\mathrm{A}(\mathrm{A} / \mathrm{T})(\mathrm{A} / \mathrm{T}) \mathrm{TAT}$ NCAT-3' (Ingraham et al., 1988; Nelson et al., 1988) and with the $5^{\prime}$ end flanked by a very AT-rich region, a characteristic found in other Pit-1-binding sites. Additional putative Pit-1 sites with different degeneracy were also observed in the structural part of the $t i G H$ gene, located in introns I, II, IV, and V and in the $5^{\prime}$-UTR. Comparison with the currently known fish $\mathrm{GH}$ genes revealed one highly conserved sequence in the region flanking the TATA box (Fig. 3). This conserved sequence (-56 GATGAATTTAAACAT -42) contains, in both orientations, a potential binding site for Pit-1.

A sequence search for perfect and imperfect, direct, and inverted repeats revealed many such structures throughout the gene. An imperfect inverted repeat at -628 bp seems to be identical to that found in the $t G H 2$ gene. On the other hand, a 67-bp imperfect direct repeat, separated by $55 \mathrm{bp}$, was found at $-2846 \mathrm{bp}$. The significance of these structures remains unknown.

\section{Trans-activation of tiGH promoter in rat pituitary cells}

The functional role of the $5^{\prime}$ flanking sequence of the $t i G H$ gene was studied by transient expression assays. To this purpose, the activity of the $-3602 /+19$ region and of three progressive $5^{\prime}$ deletion mutants fused to the luciferase gene were tested in rat pituitary GC cells, which express both GH and Pit1, and in nonpituitary EPC or COS cells, which express neither GH nor Pit-1 (Fig. 4). The promoterless construct (p0-Luc) and pCMV-Luc, which contains the promoter/enhancer of the immediate early region of the human cytomegalovirus, were used as negative and positive controls, respectively. The 3.6$\mathrm{kb} t i G H$ promoter region was able to drive high luciferase activity in GC cells but not in EPC or in COS cells, in contrast to the positive control pCMV-Luc, which displayed a high level of expression in the three cell types.

Transfection of GC cells with $5^{\prime}$ deletion mutants containing $3602,2863,1292$, and 463 bp of the $t i G H$ upstream region in front of the $L u c$ gene revealed two regulatory regions: a strongly activating region downstream from -2863 and a weakly inhibitory region between coordinates -2863 and -3602 . All deletion mutants were transcriptionally active in GC cells. The $\mathrm{p}(-2863 /+19) \mathrm{tiGH}-\mathrm{Luc}$ construct drove the highest luciferase activity. Thus, the $-463 /+19$ proximal promoter, which contains six potential Pit-1-binding sites, is sufficient to mediate high and specific trans-activation in Pit-1producing GC cells; and the -2863 to -463 region, which contains additional potential Pit-1-binding sites, is required for optimal responsiveness.

To confirm the binding of Pit-1 to the $t i G H$ promoter, we selected the most proximal $(-56 /-42)$ upstream putative bind- 
| | ||||| || ||| ||||||||||||||| ||

11

(1)

CTTTAATATTATATTAAGGTGTTAATTTAAACAGAGGTTTAACACACACACACACACACACACACACACACTGGTTGT

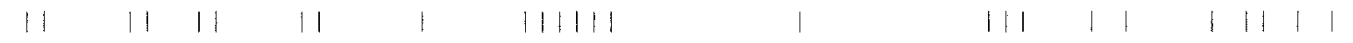
TTTACTGATAGTTCCATAGTC.ACATACAAAAACAGGTCCCATCGGCGAGAGGTGGTACATGGAGAACATCTCTTGCT. . |||||||||||||||||||||||||||||||||||||||||||||||||||||||||||||||||||||| TTTACTGATTGTTCCATAGTC. ACATACAAAAACAGGTCCCATCGGCGAGAGGTGGTACATGGAGAAAATCTCATGTT. .

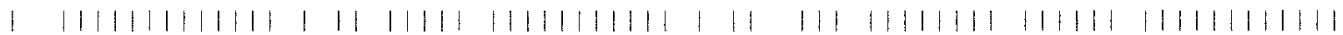
TACACTGATTGTTCCACAATC.ACATAGAAAAACAGGTCACTTCAACGAAAGGTGGTAAATGGAGGAAATCTCATGTT. . ||||||| || | || | |||| | | | | | || |||||||||||| TACACTGGTTCGTATGGTGTCTAAATACACGCAGCAATGCATAATCAAACATAGTTCTCATG. . GAAACTCTCATGTT . . $\||||| \quad|||||||||||||||||||||||||\quad|||||||||||||||$ AACACTAATGTTTTT . . . GTCTAAATACATGTAGC. ATGCATATTAAA. . . . . . . GCAAG. . GAAACTATCATGTT. .

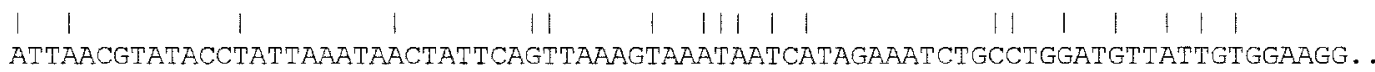
tilapia mossambica barramundi chum salmon rainbow trout atlantic salmon common carp grass carp catfish
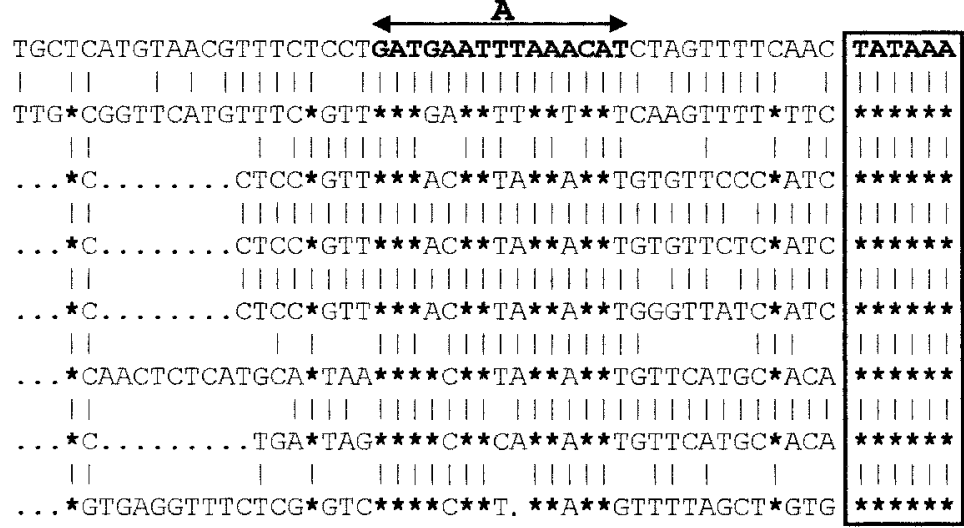

RGCAAAAACTCTGAGCTGAAAACA $1|1| 1|1\|\|\|11 \mid 1\| 11$ ACCACAAA . CTGAGCTGAAAACA 111 1 11 1 | | AACAGTGGCCCCGAACAAGCGGCA

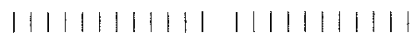
AACAgTGGCCCCAAACAAGCGGCA $1|1| 1|1||1| 1|1| 1|1| 1|1|$ AACAGTGGCCCCAAACAAACGGCA $\mathrm{T}$ tatcag . tacctgagcctgaAaA

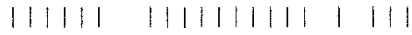
tatcagtatacCTgagccaggaAa 111 l | | 1 1 |11। aATCGgGCCAgCACAACGAgGgaC

tilapia mossambica

barramundi

chum salmon

rainbow trout

atlantic salmon

common carp

grass carp

catfish

FIG. 3. Alignment of the promoter regions from known fish GH genes. Asterisks represent nucleotides that are identical in all eight sequences. Conserved promoter regions (A) are indicated. The tsp is designated +1 . The putative TATA box is framed. Gaps $(\cdot)$ were introduced to obtain best alignment.

ing site for further investigation. Gel retardation experiments were carried out with an oligonucleotide corresponding to this site (tiGHF1). Incubation of this probe (Fig. 5, lane 8) in the presence of GC cell nuclear extracts generated two specific complexes (lane 1; Pit-1 monomer and Pit-1 dimer). These complexes were abolished in the presence of the specific competitors tiGHF 1 or tiP1 (lanes 2 and 3), the proximal Pit-1 site from the tilapia prl promoter (Poncelet et al., 1996). In the presence of nonspecific competitors (lanes 4 and 5), Spl or the thyroid hormone response element DR-4, these two complexes were not affected, whereas the slowly migrating nonspecific complex disappeared completely. Addition of antibodies directed against Pit1 (lane 6), but not of preimmune serum (lane 7), completely abolished the Pit-1 complexes. To test the transcriptional activity of this site, two copies of a tiGHF1 oligonucleotide were inserted upstream of the $\mathrm{Tk}$ promoter/luciferase reporter gene (p2xtiGHF1-Tk-Luc). Transient transfection of this construct into GC cells led to a twofold enhancement of transcription compared with the control Tk-Luc plasmid (Fig. 6).

Activation of a tiGH-Luc fusion gene by coexpression of rat Pit-1 in nonpituitary cells

To investigate further whether Pit-1 is involved in $t i G H$ gene expression, we tested the ability of the rat Pit-1 to trans-activate the $t i G H$ promoter in nonpituitary cell lines. As shown in Figure 7, a dramatic (10- to 80-fold) stimulation of $\mathrm{p}(-463 /+19) \mathrm{tiGH}-\mathrm{Luc}$ expression was observed in the presence of increasing amounts of pRSV-rPit-1 expression vector compared with cotransfection with an equivalent molar amount of the pRSV-CAT control vector.

\section{Nervous system-specific expression of a tiGH-LacZ fusion gene in zebrafish embryos}

As the $t i G H$ proximal promoter is specifically active in rat pituitary GC cells, we tested whether it would be able to drive cell-specific transient expression of a reporter gene in developing zebrafish. An expression plasmid encoding the $\beta$-galactosidase gene controlled by the $-463 /+19 t i G H$ proximal promoter was microinjected into zebrafish embryos at the one- to two-cell stage (Argenton et al., 1996a). After 24 h of development, embryos were stained for $\beta$-galactosidase activity with the chromogenic substrate X-Gal and examined under the microscope for specific blue coloration. No staining was observed in uninjected embryos (data not shown). In injected surviving embryos, an intense nonspecific expression was observed in the yolk sac endoderm surrounding the yolk of some embryos (see Discussion). In addition, in 5 of the 30 survivors, blue staining was detected specifically at the level of the developing nervous system. The staining was restricted either to the midbrain-hindbrain boundary (three embryos) (Fig. 8, arrow) or to the neural tube (two embryos). 
Transcriptional inhibition by a potential Pit-1 site located downstream from the transcription start point

To investigate the biologic function of the potential Pit1-binding site tiGHF0 $(+20 /+30)$, located in the $5^{\prime}$-UTR of the tiGH gene, $t i G H$ reporter plasmids either containing $(\mathrm{p}(-463 /$ $+40) \mathrm{tiGH}-\mathrm{Luc})$ or lacking $(\mathrm{p}(-463 /+19) \mathrm{tiGH}-\mathrm{Luc})$ this site were evaluated in transient expression assays (Fig. 9). Addition of the sequences from +19 to +40 resulted in a fourfold decrease in activity in GC cells (Fig. 9A) and in EPC cells cotransfected with pRSV-rPit-1 (Fig. 9B). When cells were grown in the absence of serum, the presence of the sequence from +20 to +40 still decreased expression to the same extent (data not shown), suggesting that the negative regulation by this Pit-1 site is independent of extracellular bovine serum factors.

Because the length of the leader sequence is different in the two constructs, the decreased expression of the $\mathrm{p}(-463 /+40)$ tiGH-Luc construct could be secondary to decreased stability of the corresponding mRNA. To address this question, we introduced minimal point mutations in the potential Pit-1-binding site (+23 ATAATCAT +31 to ATG ATCG A) that would be likely to block Pit-1 binding without affecting the resulting mRNA size. This mutation in $\mathrm{p}(-463 /+40)$ tiGH-Luc resulted in a fourfold increase in luciferase expression in GC cells (Fig. 9A) as well as in EPC cells cotransfected with pRSV-rPit-1 (Fig. 9B), restoring an activity similar to that of $\mathrm{p}(-463 /$
+19)tiGH-Luc. Taken together, these data demonstrate that the transient expression of the $t i G H$ promoter is inhibited by a potential Pit-1-binding site (tiGHF0) located in the $5^{\prime}$-UTR.

Pituitary proteins from rat, tilapia, and trout bind specifically to potential Pit-1-binding site tiGHFO

Electrophoretic mobility shift assays were perform ed to identify proteins interacting with the tiGHF0 inhibitory site. Incubation of nuclear extracts derived from GC cells with a labeled oligonucleotide, hGHF1, containing the proximal Pit-1-binding site of the human GH promoter resulted in the formation of three protein-DNA complexes (Ca, Cc, Cd) (Fig. 10A; lane 2). $\mathrm{Ca}$ and $\mathrm{Cc}$, previously shown to represent Pit-1 monomeric and dimeric complexes, respectively (Lefevre et al., 1987), disappeared in the presence of a 200 -fold molar excess of unlabeled hGHF1 or tiGHF0 oligonucleotides (lanes 3 and 4), whereas competition using tiGHF0m, an oligonucleotide mutated in the Pit-1 consensus, was very weak (lane 5). Complex Cd was not affected by unlabeled hGHF1 or tiGHF0 and thus was considered to be nonspecific. The unrelated AP-1 oligonucleotide failed to compete for any of these complexes (lane 6).

When a labeled tiGHF0 oligonucleotide was incubated with GC nuclear extracts, two complexes were detected having electrophoretic mobilities identical to those of the Pit-1 complexes

A

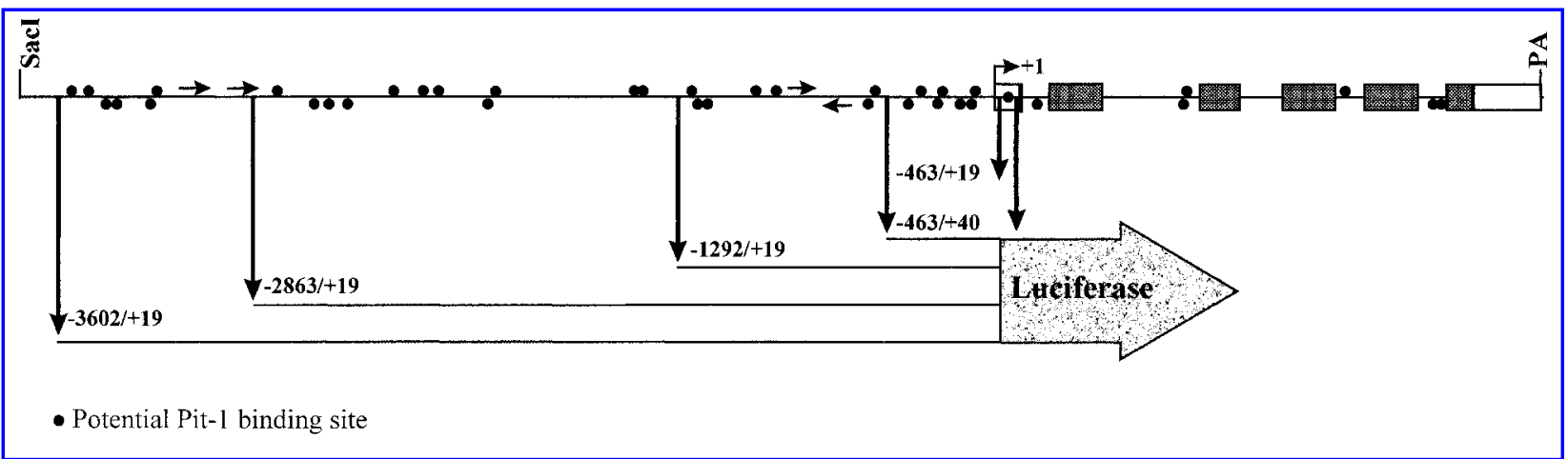

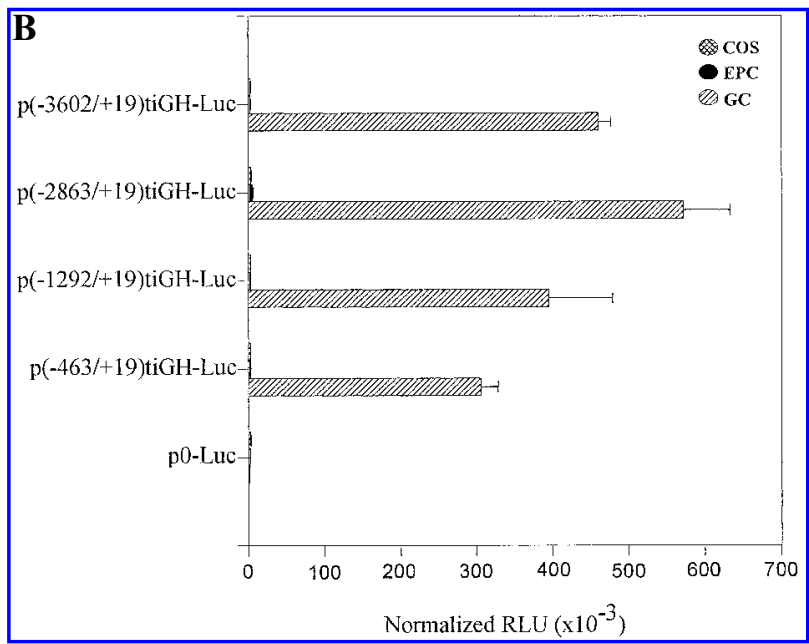

FIG. 4. Effects of $5^{\prime}$ deletion mutants of the tilapia $t i G H$ upstream region on transient luciferase expression. A. Schematic representation of the $t i G H$ promoter deletion mutants. Dots indicate the putative Pit-1-binding sites $\mathbf{B}$. The indicated reporter plasmids plus $1 \mu \mathrm{g}$ of $\mathrm{pCMV}-\beta \mathrm{gal}$, as an internal control, were transfected into GC, EPC, and COS cells. After 2 days, cellular LUC activity was assayed and normalized to $\beta$-galactosidase activity. Values are the means \pm SE from five independent transfection experiments (except for EPC and COS cells, where the data represent the mean \pm SE from two experiments) performed in duplicate. 


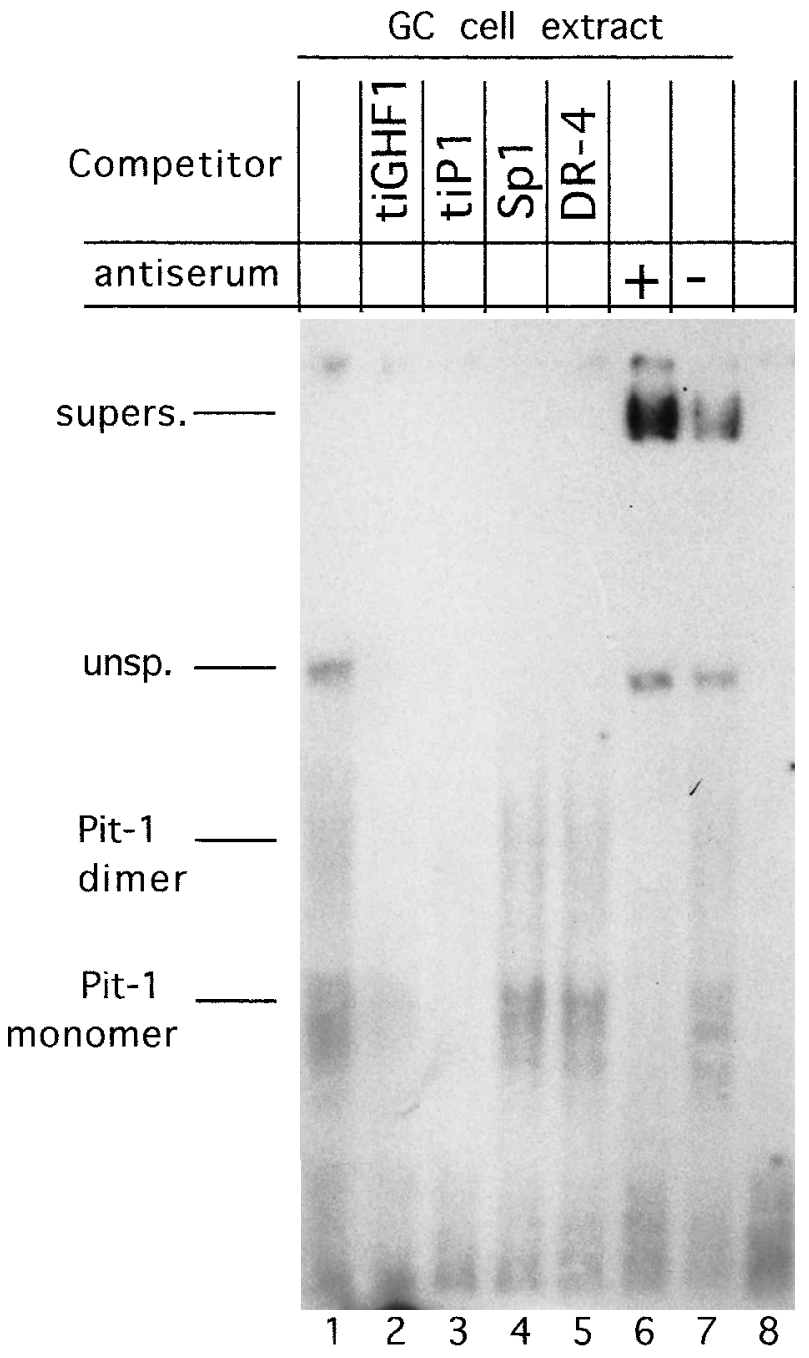

FIG. 5. Gel retardation analysis of the tiGHF1 site. End-labeled tiGHF1, corresponding to the proximal putative upstream Pit-1-binding site of the $t i G H$ promoter, was incubated with 3 $\mu \mathrm{g}$ of GC nuclear extract (lane 1). For competition experiments, a 100-fold molar excess of unlabeled oligonucleotide tiGHF1 (lane 2), tiP1 (lane 3), Sp1 (lane 4), or DR-4 (lane 5) was added to the reaction mixture. Supershift assays were performed using $1 \mu \mathrm{l}$ of crude antiserum raised against the $\mathrm{N}$-terminal part of the human Pit-1 protein (lane 6) or the corresponding preimmune serum (lane 7).

Ca and Cc (lane 8). Addition of a 200-fold molar excess of unlabeled tiGHF0 or hGHF1 oligonucleotides suppressed the two complexes (lanes 9 and 11), whereas the tiGHF0m and AP1 oligonucleotides did not (lanes 10 and 12). Furthermore, addition of a Pit-1-specific antiserum resulted in supershift of the complexes (lane 13). An additional complex (Cb), with an intermediate mobility, was considered to be nonspecific, as it was unaffected by specific competitors or Pit-1 antibodies.

As the above results indicated that rat Pit-1 can bind to the tilapia tiGHF0 site, we sought to determine whether tilapia pituitary cells contain a Pit-1-related factor able to bind to this sequence. When a labeled tiGHF0 oligonucleotide was incu- bated with tilapia pituitary extracts, three protein complexes appeared (tiCa, tiCb, and tiCc) (Fig. 10B; lane 4). Formation of these complexes was blocked by an excess of the human hGHF1-bind ing site (lane 5). Because the weak tiCa complex migrated at the same position as the strong, nonspecific complex $\mathrm{Cb}$ obtained using GC cells (lanes 2 and 3), we assume that the complexes tiCb and tiCc correspond to the monomeric and dimeric Pit-1 forms, respectively. Both complexes migrated more slowly when formed using tilapia (lane 4) or trout (lane 6) pituitary extracts, suggesting that the tilapia Pit-1-like protein is larger than its rat counterpart. Thus, the EMSA data indicate that rat Pit-1 and a tilapia Pit-1-like protein specifically interact with the potential tiGHF0 binding site located in the $5^{\prime}$-UTR of the $t i G H$ gene.

\section{DISC USSION}

We describe the cloning, sequence analysis, and potential cis-acting regulatory elements responsible for the pituitary specific-expression of the $t i G H$ gene. Sequence analysis reveals a high similarity to other known GH genes within the coding sequences but much smaller introns. The $t i G H$ gene six-exon/fiveintron structure confirms that the introduction of an additional intron $\mathrm{V}$ into fish $\mathrm{GH}$ genes took place after the diversification of teleosts but before the divergence of perciforms and salmoniforms (Chiou et al., 1990; Zhu et al., 1992; Hong and Schartl, 1993; Tang et al., 1993).

Analysis of the $5^{\prime}$ flanking region of the $t i G H$ gene revealed two 39-bp inverted repeat sequences separated by $116 \mathrm{bp}$, forming a transposon-like structure $628 \mathrm{nt}$ upstream from the transcription start site. It is not related to the major repetitive DNA family found in tilapia (Wright, 1989) nor to the highly repetitive POL III/SINE sequence present in the salmon genome (Matsumoto et al., 1986). Furthermore, no effect on transcriptional regulation was observed. We also found two 67-bp imperfect repeated sequences centered at -2846 and separated by $55 \mathrm{bp}$, without any significant homology with known transcription factor binding sites. Deletion of this sequence weakly but significantly increased the activity of $t i G H$ in GC cells, suggesting that it corresponds to a negative regulatory element.

In mammals, the promoter/enhancer regions of the GH gene have been extensively characterized with respect to their tissuespecific expression. Deletion analysis and DNase-I footprinting experiments identified a DNA sequence motif that is required for the pituitary-specific expression of the GH promoter. This motif, 5'-A(A/T)(A/T)TATNCAT-3', is the binding site for the pituitary-specific factor Pit-1. This transcription factor belongs to the POU homeodomain proteins and is essential for the trans activation of the GH, $\beta$-TSH, Prl, and Pit-1 genes. A computer search for such Pit-1-binding sites in the $5^{\prime}$ flanking region of the $t i G H$ gene revealed several sequences identical to the consensus Pit-1 core binding site or differing from it by only one or two mismatches. All these potential binding sites are flanked by a very AT-rich region, a characteristic found in other Pit-1binding sites. In light of the dependence of Pit-1 binding on nucleotide changes (Elsholtz et al., 1990, Ono et al., 1995), some of these sites may not be functional. 


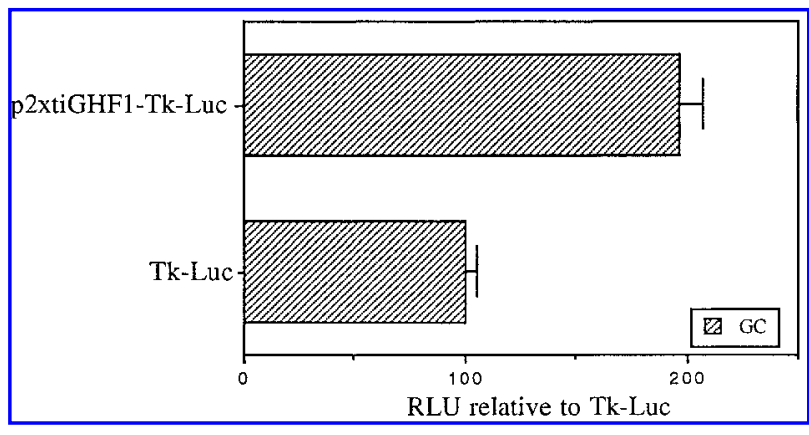

FIG. 6. Activation mediated by the Pit-1 site tiGHF1 to a heterologous promoter. Two copies of the tiGHF1 site were cloned upstream from the heterologous Tk promoter (2xtiGHF1-TkLuc), and the transcriptional activity was compared with that of the parental Tk-Luc construct. Values are the means $\pm \mathrm{SE}$ from three independent transfection experiments performed in duplicate.

Transfection experiments in rat pituitary GC cells and in nonpituitary EPC and COS cells using tiGH promoter/luciferase fusion constructs resulted in high expression only in GC cells. A $5^{\prime}$ deletion analysis led to the identification of a weak negative region and a strong positive one in GC cells. The first one $(-2863 /-3602)$ contained the imperfect direct repeat mentioned above. Its possible involvem ent in negative regulation remains to be explored. Within the second region, between -2863 and the tsp, the most proximal $463 \mathrm{bp}$ are sufficient to direct high-level pituitary-specific expression. Interestingly, six potential Pit-1-binding sites were mapped in this region, and we showed that the most proximal one $(-56 /-42)$, which is

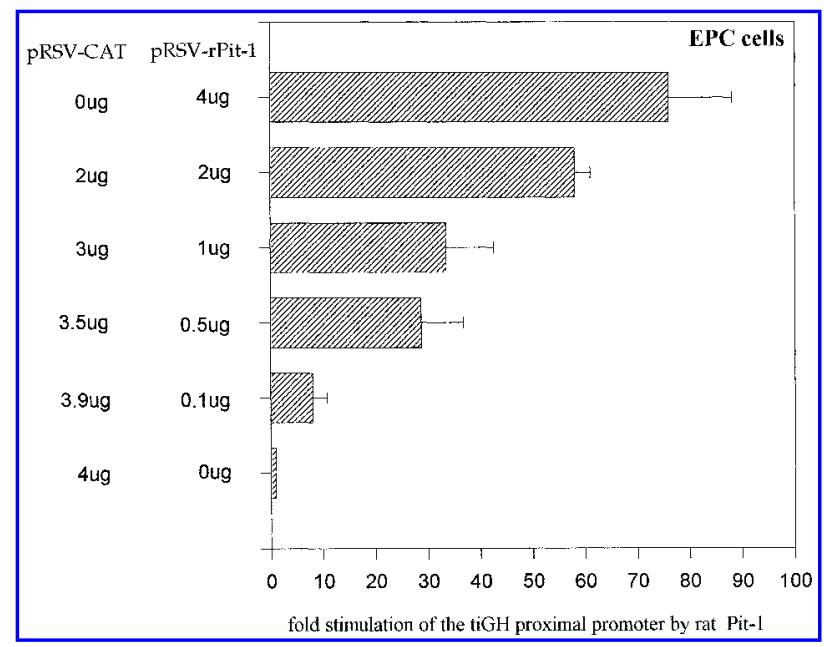

FIG. 7. Stimulation of $t i G H$ proximal promoter activity by rat Pit-1 in nonpituitary cells. Carp EPC cells were cotransfected by the calcium phosphate method with 2 pmoles of $\mathrm{p}(-463 /+19)$ tiGH-Luc and $0.1,0.5,1,2$, or $4 \mu \mathrm{g}$ of pRSVrPit-1 expression plasmid for rat Pit-1. The pRSV-CAT expression plasmid was used as a negative control, and a pCMV$\beta$ gal $(1 \mu \mathrm{g})$ was included to normalize the values for transfection efficiency. After $52 \mathrm{~h}$, luciferase and $\beta$-galactosidase activities were measured. Results are the mean \pm SE of four experiments, each performed in duplicate. highly conserved among the currently known fish GH genes (Yamada et al., 1993; Argenton et al., 1996b), is functionally active, as it specifically binds Pit-1 in gel retardation experiments and confers activation to the Tk promoter in GC cells. All the $5^{\prime}$ deletion mutants tested were highly expressed only in pituitary GC cells. The $t i G H$ promoter was enhanced after coexpression of rat Pit-1 in EPC (see Fig. 7) or COS cells (data not shown), showing that Pit-1 might be responsible for the trans-activation observed in GC cells in good correlation with the high conservation of Pit-1 structure (Ono and Takayama, 1992) and functions (Elsholtz et al., 1992; Argenton et al., 1996b) from fish to mammals.

Tissue-specific regulatory elements have been studied in transiently transgenic fish. Rinder et al. (1992) confirmed that the regulatory sequences from the zebrafish ependymin gene (the predominant glycoprotein in the cerebrospinal fluid of fish, thought to be involved in cell adhesion phenomena) drive expression of the $L a c Z$ gene in an ependym in-specific manner in zebrafish embryos. Similarly, heterologous regulatory sequences from the rat $G A P-43$ gene (which codes for a major component of the neuronal growth cones) driving the LacZ gene were specifically activated in the embryonic nervous system (Reinhard et al., 1994). Thus, as the proximal promoter region was sufficient to confer pituitary-specific expression on the $t i G H$ promoter in cell lines, we extended our study to microinjected zebrafish embryos. We observed that the proximal re-

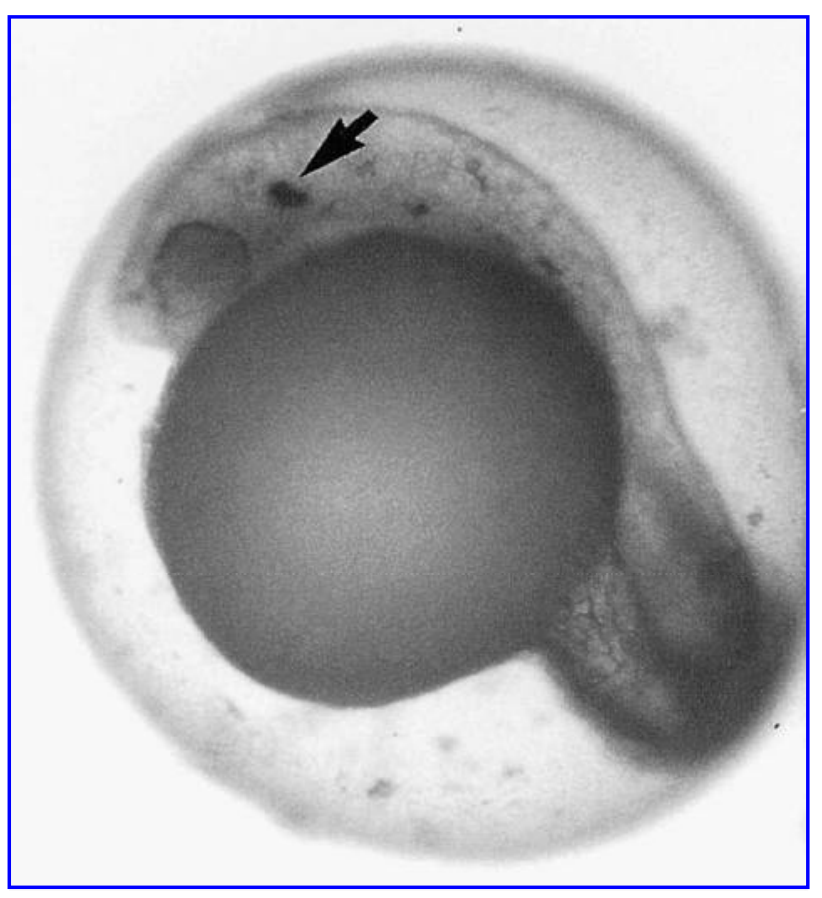

FIG. 8. $\beta$-Galactosidase activity in zebrafish embryos injected with a tilapia mossambica $\mathrm{GH}$ promoter directing $\beta$ galactosidase expression. Embryos ( 1 to 2 cells) were injected with $\mathrm{p}(-463 /+19)$ tiGH- $\beta$ gal. After $24 \mathrm{~h}$, the embryos were fixed and incubated with X-Gal to visualize $\beta$-galactosidase activity. A representative embryo is shown at $\times 55$ magnification. The arrow indicates specific $\beta$-Gal expression. Blue cells were identified on the basis of their location in spinal cord or brain. 

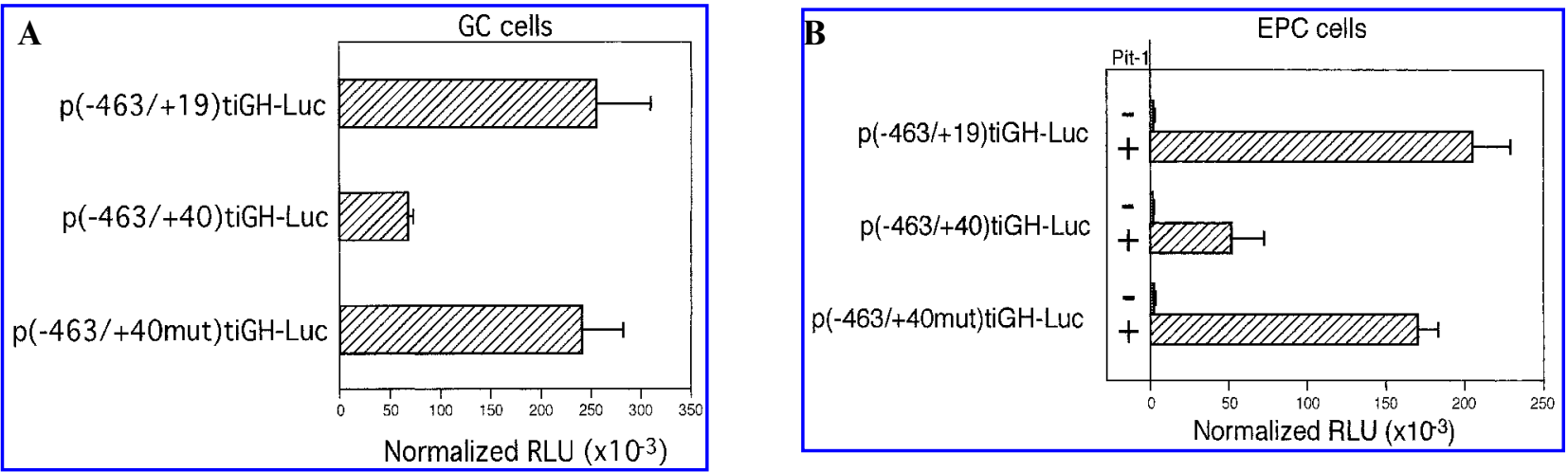

FIG. 9. Effect of downstream Pit-1-binding site tiGHF0 on transient Luc gene expression in GC cells. A. Reporter plasmids (4 pmoles) containing the $t i G H$ promoter sequences $(-463 /+19)$, the wild type $-463 /+40$ region, or the $-463 /+40$ region mutated in the potential downstream Pit-1-binding site $(+19 /+40)$ were transfected into GC cells or EPC cells transfected with the pRSV-rPit- 1 expression vector $(\mathbf{B} ;+)$. In addition, $1 \mu \mathrm{g}$ of pCMV- $\beta$ gal was cotransfected as a control for transfection efficiency. After 2 days, luciferase activities were determined and normalized to the $\beta$-galactosidase activity. Values are the means \pm SE of duplicate experiments performed at least twice.

A

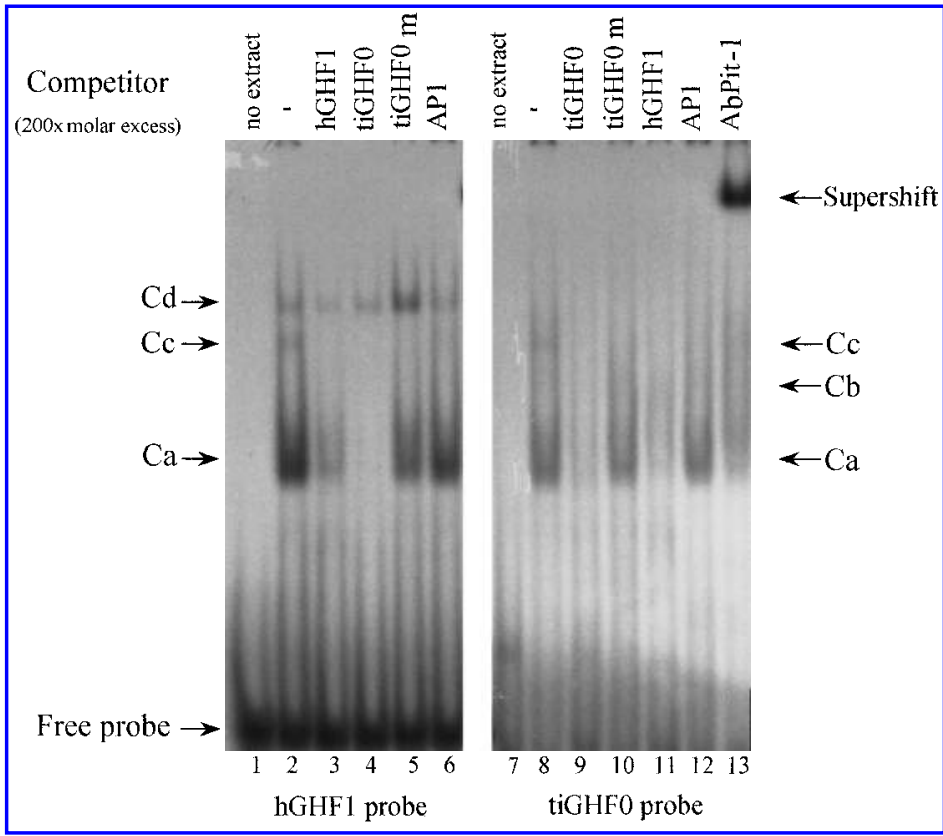

B

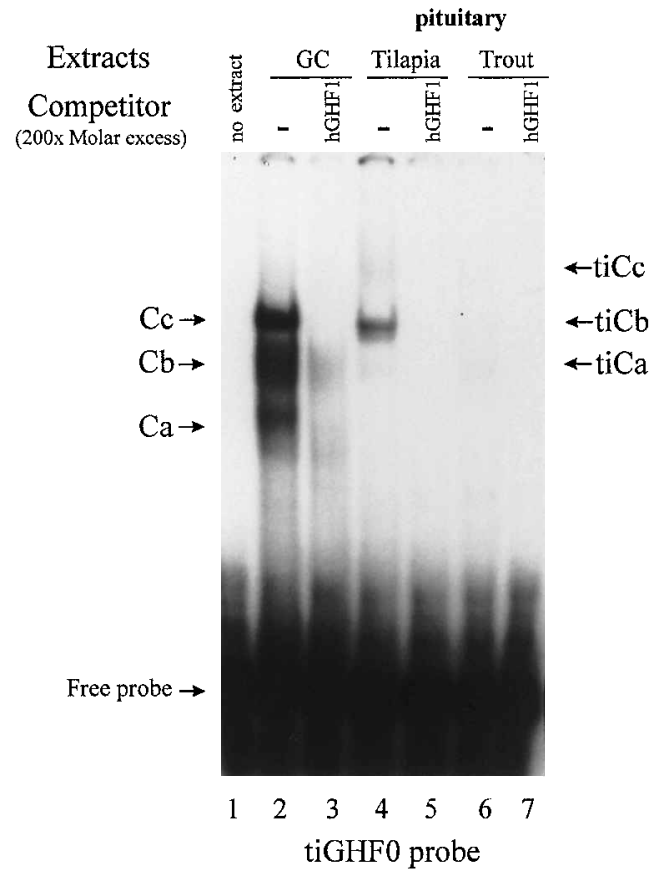

FIG. 10. Gel-shift analysis of the hGHF1 and tiGHF0 oligonucleotides. A. End-labeled hGHF1, corresponding to the first Pit1-binding site of the human GH promoter, and tiGHF0, which contains the Pit-1 site localized in the $5^{\prime}$-UTR, were incubated with GC nuclear extract (3 $\mu \mathrm{g}$ ). For competition experiments, 200-fold molar excess of the unlabeled oligonucleotide hGHF1 (lanes 2 and 9), tiGHF0 (lanes 3 and 8), tiGHF0m (lanes 4 and 10), and AP-1 (lanes 5 and 11) were added to the reaction mixture. Supershift assays were perform ed using $1 \mu \mathrm{l}$ of crude antiserum raised against the N-terminal part of the human Pit-1 protein (lanes 6 and 12). B. End-labeled tiGHF0 was incubated in the absence (lane 1) or presence (lanes 2 and 3 ) of $3 \mu \mathrm{g}$ of GC nuclear extract, $15 \mu \mathrm{g}$ of tilapia pituitary nuclear extract (lanes 4 and 5), or $15 \mu \mathrm{g}$ of trout pituitary nuclear extract (lanes 5 and 6). Competitions were performed using a 200 -fold molar excess of unlabeled hGHF1 (lanes 3, 5, and 7).

gion of the $t i G H$ promoter is sufficient to direct expression specifically to the developing nervous system, in particular to the area at the midbrain-hindbrain boundary. This expression correlates well with the first, early phase of Pit-1 (and other POU-homeodomain factor) expression in neural tissue during rat development (He et al., 1989). We did not detect specific expression of the transgene in the pituitary using this approach, probably because of the mosaic distribution and dilution of the injected DNA in the embryos. Note that in some embryos, there was an intense expression in the yolk sac endoderm. This ec- 
topic high-level transgene expression was probably attributable to the differential replication of transgene copies in multinucleated or polyploid tissues such as the yolk syncytial layer (Williams et al., 1996).

In the rat, Pit-1 autoregulates its own expression by binding to two sites. The first one, named PitB1, is located in the promoter and mediates strong stimulation of transcription, whereas occupancy of the PitB2 site, located just downstream of the transcription initiation site, results in attenuation of the stimulatory effects of PitB1, reflecting either decreased efficiency of transcriptional initiation or attenuation of nascent transcripts (Chen et al., 1990). Smith and Sharp (1991) demonstrated in vitro that Pit-1 interaction with the downstream site represses the activity of the Pit-1 gene by blocking the elongation by RNA polymerase II through the occupied binding site. Cis-acting interactions of this type might also regulate elongation during $t i G H$ gene transcription, as several potential binding sites for Pit-1 were found within the structural part of this gene. The most interesting one is located in the $5^{\prime}$-UTR, as it appears to be somewhat similar to the PitB2 site found in the $5^{\prime}$-UTR of the rat Pit-1 gene. Indeed, when the $+19 /+40$ sequence, encompassing the potential Pit-1-binding site (tiGHF0), was either deleted or mutated, a fourfold increase in expression of $\mathrm{p}(-463 /+40) \mathrm{tiGH}-\mathrm{Luc}$ was observed. The EMSA experiments, using the potential downstream Pit-1-binding site tiGHF0 as a probe, clearly showed that Pit-1 specifically binds to this site. This effect was independent of the presence of serum and was also obtained in EPC cells cotransfected with a rat Pit-1-expression vector.

Thus, our results indicate that the single Pit-1-binding site downstream of the transcription start site negatively regulates expression of the $t i G H$ gene. The mechanism for this repression could be similar to the one shown for the rat Pit-1 gene. However, we cannot rule out the possibility that binding to the Pit-1 site in the $t i G H$ gene inhibits transcription by sterically interfering with the formation of the transcription initiation complex. A similar role for other putative Pit-1 sites in the transcribed region remains to be established, but our observations and the fact that such sites are absent in mammalian GH genes raise the possibility of a more refined regulation of the transcription of this gene in lower vertebrates. This is the first time, except for the negative feedback regulation of Pit-1 itself, that repression by Pit- 1 of a gene specifically expressed in the pituitary has been observed.

The ability of rat Pit-1 to interact with the downstream consensus sequence in the $5^{\prime}$-UTR of the $t i G H$ gene suggests the occurrence of a Pit-1 homolog in tilapia. In the presence of tilapia pituitary nuclear extracts, we observed specific complexes with the tiGHF0 oligonucleotide. These complexes correspond to the binding of a monomer (tiCb) or a dimer (tiCc) of a tilapia Pit-1-like factor. Fish (chum salmon and rainbow trout) cDNAs encoding the Pit-1 factor have been cloned (Ono and Takayama, 1992; Yamada et al., 1993). The salmonid Pit1 proteins are larger than rat Pit-1, as they contain two insertions of about 30 aa each in their N-terminal part. This explains why the complexes obtained with trout pituitary extracts migrated more slowly than those observed with rat GC cell extracts in EMSA experiments. Interestingly, the protein-DNA complexes observed using the tilapia pituitary extracts migrate to the same position as those observed using trout pituitary ex- tracts, suggesting that the tilapia Pit-1 might be of a size similar to that of the other characterized fish Pit-1.

\section{ACKNOWLEDGMENTS}

The authors are grateful to Dr. Michael Karin for the generous gift of the pRSV-rPit-1 expression vector and Dr. Manfred Schartl for providing the p0-Luc plasmid. We thank Dr. Dominique Sweenen for kindly providing the genomic library and Dr. Françoise Rentier-Delrue for kindly providing a $t i G H$ cDNA probe. We also thank Dr. Corine Lecomte and Daniele Vandenbergh (Eurogentec, Belgium) for their help with the EPC cell cultures.

This work was funded by the European Community (BRIDGE program BIO2-CT94-2039), the "Services Fédéraux des Affaires Scientifiques, Techniques et Culturelles PAI P3044 and PAI P3-042," and the "Fonds National de la recherche Scientifique" (F.R.F.C. 2.9006.91), Belgium. B.S. was the holder of a doctoral fellowship from the European Community. F.A. was the recipient of an EC postdoctoral fellowship (AIR2 CT93-1543 project). M.M. held a position at the Fonds National de la Recherche Scientifique.

\section{REFERENCES}

AGELlON, L.B., DAVIES, S.L., CHEN, T.T., and POWERS, D.A. (1988). Structure of a fish (rainbow trout) growth hormone gene and its evolutionary implications. Proc. Natl. Acad. Sci. USA 85, $5136-5140$.

ANDERSEN, B., and ROSENFELD, M.G. (1994). Pit-1 determines cell types during development of the anterior pituitary gland: a model for transcriptional regulation of cell phenotypes in mammalian organogenesis. J. Biol. Chem. 269, 29335-29338.

ANGEL, P., IMAGAWA, M., CHIU, R., STEIN, B., IMBRA, R.J., RAHMSDORF, H.J., JONAT, C., HERRLICH, P., and KARIN, M. (1987). Phorbol ester-inducible genes contain a common cis element recognized by a TPA-modulated trans-acting factor. Cell 49, $729-739$.

ARGEnTON, F., ARAVA, Y., ARHONHEIM, A., and WALKER, M.D. (1996a). An activation domain of the helix-loop-helix transcription factor E2A shows cell type preference in vivo in microinjected zebra fish embryos. Mol. Cell. Biol. 16, 1714-1721.

ARGENTON, F., BERNARDINI, S., PUTTINI, S., COLOMBO, L., and BORTOLUSSI, M. (1996b). A TGACG motif mediates growth-hormone-factor-1/pituitary-transcriptional-activator -1 dependent cAMP regulation of the rainbow trout growth-hormone promoter. Eur. J. Biochem. 238, 591-598.

BARRON, M.G. (1986). Endocrine control of smoltification in anadromous salmonids. J. Endocrinol. 108, 313-319.

BARTA, A., RICHARDS, R.I., BAXTER, J.D., and SHINE, J. (1981). Primary structure and evolution of rat growth hormone gene. Proc. Natl. Acad. Sci. USA 78, 4867-4871.

BER, R., and DANIEL, V. (1992). Structure and sequence of the growth hormone-encoding gene from Tilapia nilotica. Gene 113, 245-250.

BER, R., and DANIEL, V. (1993). Sequence analysis suggests a recent duplication of the growth hormone-encoding gene in Tilapia nilotica. Gene 125, 143-150.

BODNER, M. and KARIN, M. (1987). A pituitary-specific trans-acting factor can stimulate transcription from the growth hormone promoter in extracts of nonexpressing cells. Cell 50, 267-275. 
BODNER, M., CASTRILLO, J.L., THEILL, L.E., DEERINCK, T., ELLISMAN, M., and KARIN, M. (1988). The pituitary-specific transcription factor GHF-1 is a homeobox-conta ining protein. Cell $\mathbf{5 5}$, 505-518.

BOLTON, J.P., COLLIE, N.L., KAWAUCHI, H., and HIRANO, T. (1987). Osmoregulatory actions of growth hormone in rainbow trout (Salmo gairdneri). J. Endocrinol. 112, 63-68.

BOSHART, M., KLUPPEL, M., SCHMIDT, A., SCHUTZ, G., and LUCKOW, B. (1992). Reporter constructs with low background activity utilizing the CAT gene. Gene 110, 129-130.

BRADFORD, M.M. (1976). A rapid and sensitive method for the quantitation of microgram quantities of protein utilizing the principle of protein-dye binding. Anal. Biochem. 72, 248-254.

BUCHER, P. (1990). Weight matrix descriptions of four eukaryotic RNA polymerase II promoter elements derived from 502 unrelated promoter sequences. J. Mol. Biol. 212, 563-578.

BYRNE, C.R., WILSON, B.W., and WARD, K.A. (1987). The isolation and characterization of the ovine growth hormone gene. Aust. J. Biol. Sci. 40, 459-468.

CHEN, R., INGRAHAM, H.A., TREACY, M.N., ALBERT, V.R., WILSON, L., and ROSENFELD, M.G. (1990). Autoregulation of pit- 1 gene expression mediated by two cis-active promoter elements. Nature 346, 583-586.

CHIOU, C.-S., CHEN, H.-T., and CHANG, W.-C. (1990). The complete nucleotide sequence of the growth hormone gene from the common carp (Cyprinus carpio). Biochim. Biophys. Acta 1087, 91-94.

DENOTO, F.M., MOORE, D.D., and GOODMAN, H.M. (1981). Human growth hormone DNA sequence and mRNA structure: possible alternative splicing. Nucleic Acids Res. 9, 3719-3730.

DEVLIN, R.H. (1993). Sequence of sockeye salmon type 1 and 2 growth hormone genes and the relationship of rainbow trout with Atlantic and Pacific salmon. Can. J. Fish. Aqua. Sci. 50, 1738-1748.

DIGNAM, J.D., LEBOVITZ, R.M., and ROEDER, R.G. (1983). Accurate transcription initiation by RNA polymerase II in a soluble extract from isolated mammalian nuclei. Nucleic Acids Res. 11, $1475-1489$.

DU, S.J., DEVLIN, R.H., and HEW, C.L. (1993). Genomic structure of growth hormone genes in chinook salmon (Oncorhynchus tshawytscha): presence of two functional genes, GH-I and GH-II, and a male-specific pseudogene, GH. DNA Cell Biol. 12, 739-751.

ELSHOLTZ, H.P., ALBERT, V.R., TREACY, M.N., and ROSENFELD, M.G. (1990). A two-base change in a POU factor-binding site switches pituitary-specific to lymphoid-specif ic gene expression. Genes Dev. 4, 43-51.

ELSHOLTZ, H.P., MAJUMDAR-SONNYLAL, S., XIONG, F., GONG, Z.Y., and HEW, C.L. (1992). Phylogenic specificity of prolactin gene expression with conservation of Pit-1 function. Mol. Endocrinol. 6, 515-522.

FIJAN, N., SULIMANOVIC, D., BEARZOTTI, M., MUZINIC, D., ZWILLENBERG, L.O., CHILMONCZYK, S., VAUTHEROT, J.F., and DE KINKELIN, P. (1983). Some properties of the epithelioma papulosum cyprini (EPC) cell line from carp Cyprinus carpio. Annu. Virol. Inst. Pasteur 134, 207-220.

GEHRING, W.J., AFFOLTER, M., and BURGLIN, T. (1994). Homeodomain proteins. Annu. Rev. Biochem. 63, 487-526.

GORDON, D.F., QUICK, D.P., ERWIN, C.R., DONELSON, J.E., and MAURER, R.A. (1983). Nucleotide sequence of the bovine growth hormone chromosomal gene. Mol. Cell. Endocrinol. 33, 81-95.

GROSSBERGER, D. (1987). Minipreps of DNA from bacteriophage lambda. Nucleic Acids Res. 15, 6737

HE, X., TREACY, M.N., SIMMONS, D.M., INGRAHAM, H.A., SWANSON, L.W., and ROSENFELD, M.G. (1989). Expression of a large family of POU-domain regulatory genes in mammalian brain development. Nature 340, 35-41.

HOLLY, J.M.P., and WASS, J.A.H. (1989). Insulin-like growth factors; autocrine, paracrine or endocrine? new perspectives of the so- matomedin hypothesis in the light of recent developments. J. Endocrinol. 122, 611-618.

HONG, Y., and SCHARTL, M. (1993). Sequence of the growth hormone $(\mathrm{GH})$ gene from the silver carp (Hypophthalmich thys molitrix) and evolution of GH genes in vertebrates. Biochim. Biophys. Acta 1174, 285-288.

INGRAHAM, H.A., CHEN, R.P., MANGALAM, H.J., ELSHOLTZ, H.P., FLYNN, S.E., LIN, C.R., SIMMONS, D.M., SWANSON, L., and ROSENFELD, M.G. (1988). A tissue-specific transcription factor containing a homeodomain specifies a pituitary phenotype. Cell $\mathbf{5 5}, 519-529$.

INOUE, K., AKITA, N., YAMASHITA, S., SHIBA, T., and FUJITA, T. (1990). Constitutive and inducible expression of a transgene directed by heterologous promoters in a trout liver cell line. Biochem. Biophys. Res. Commun. 173, 1311-1316.

JOHANSEN, B., JOHNSEN, O.C., and VALLA, S. (1989). The complete nucleotide sequence of the growth hormone gene from Atlantic salmon (Salmo salar). Gene 77, 317-324.

LEFEVRE, C., IMAGAWA, M., DANA, S., GRINDLY, J., BODNER, M., and KARIN, M. (1987). Tissue-specific expression of the human growth hormone gene is conferred in part by the binding of a specific trans-acting factor. EMBO J. 6, 971-981.

MACGREGOR, G.R., and CASKEY, C.T. (1989). Construction of plasmids that express E. coli $\beta$-galactosidase in mammalian cells. Nucleic Acids Res. 17, 2365.

MALE, R., NERLAAND, A.H., LORENS, J.B., TELLE, W., LOSSIUS, I., and TOTLAND, G.K. (1992). The complete nucleotide sequence of the Atlantic salmon growth hormone I gene. Biochim. Biophys. Acta 1130, 345-348.

MANGALAM, H.J., ALBERT, V.R., INGRAHAM, H.A., KAPILOFF, M., WILSON, L., NELSON, C., ELSHOTZ, H., and ROSENFELD, M.G. (1989). A pituitary POU domain protein, Pit-1, activates both growth hormone and prolactin promoters transcriptionally. Genes Dev. 3, 946-958.

MATSUMOTO, K.-I., MURAKAMI, K., and OKADA, N. (1986). Gene for lysine tRNA1 may be a progenitor of the highly repetitive and transcribable sequences present in the salmon genome. Proc. Natl. Acad. Sci. USA 83, 3156-3160.

MILLER, W.L., and EBERHARDT, N.L. (1983). Structure and evolution of the growth hormone gene family. Endocr. Rev. 4, 97-129.

MILLER, W.L., MARTIAL, J.A., and BAXTER, J.D. (1980). Molecular cloning of DNA complementary to bovine growth hormone in mRNA. J. Biol. Chem. 255, 7521-7524.

MIWA, S., and INUI, Y. (1985). Effects of L-thyroxine and ovine growth hormone on smoltification of amago salmon (Oncorhynchus rhodurus). Gen. Comp. Endocrinol. 58, 436-442.

MOORE, D.D., WALKER, M.D., DIAMOND, D.J., CONKLING, M.A., and GOODMAN, H.M. (1982). Structure, expression and evolution of growth hormone genes. Recent Prog. Horm. Res. 38, $197-225$.

MOUNT, S.M. (1982). A catalogue of splice junction sequences. $\mathrm{Nu}-$ cleic Acids Res. 10, 459-472.

NELSON, C., ALBERT, V.R., ELSHOLTZ, H.P., LU, L.I.-W., and ROSENFELD, M.G. (1988). Activation of cell-specific expression of rat growth hormone and prolactin genes by a common transcription factor. Science 239, 1400-1405.

NORDEEN, S.K. (1988). Luciferase reporter gene vectors for analysis of promoters and enhancers. Biotechniques 6, 454-457.

ONO, M., and TAKAYAMA, Y. (1992). Structures of cDNAs encoding chum salmon pituitary-specif ic transcription factor, Pit-1/GHF1. Gene 126, 275-279.

ONO, M., MOCHIZUKI, E., MORI, Y., AIZAWA, A., and HARIGAI, T. (1995). The regulatory region and transcription factor required for the expression of rat and salmon pituitary hormone-encod ing genes show cell-type and species specificity. Gene 153, 267-271.

PERNASETTI, F., MILNER, R.D.G., AL ASHWAL, A.A.Z., DE 
ZEGHER, F., CHAVEZ, V.M., MULLER, M., and MARTIAL, J.A. (1998). Pro239Ser: a novel recessive mutation of the Pitl gene in seven Middle Eastern children with combined pituitary hormone deficiency. J. Clin. Endocrinol. Metab. 83, 2079-2083.

PONCELET, A., MULLER, M., YARON, Z., MARTIAL, J.A., and BELAYEW, A. (1996). The Tilapia prolactin I gene: evolutionary conservation of the regulatory elements directing pituitary-specif ic expression. DNA Cell Biol. 15, 679-692.

PROUDFOOT, N.J., and BROWNLEE, G.G. (1976). 3'-Non-coding region sequences in eukaryotic messenger RNA. Nature 263, 211 214.

RAND-WEAVER, M., SWANSON, P., KAWAUCHI, H., and DICKHOFF, W.W. (1992). Somatolactin, a novel pituitary protein: purification and plasma levels during reproductive maturation of Coho salmon. J. Endocrinol. 133, 393-403.

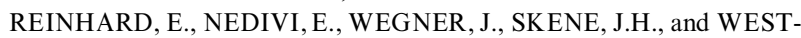
ERFIELD, M. (1994). Neural selective activation and temporal regulation of a mammalian GAP-43 promoter in zebrafish. Development 120, 1767-1775.

RENTIER-DELRUE, F., SWENNEN, D., PHILIPPART, J.C., L'HOIR, C., LION, M., BENRUBI, O., and MARTIAL, J.A. (1989). Tilapia growth hormone: molecular cloning of cDNA and expression in Escherichia coli. DNA 8, 271-278.

RINDER, H., BAYER, T.A., GERTZEN, E.M., and HOFFMAN, W. (1992). Molecular analysis of the ependymin gene and functional test of its promoter region by transient expression in Brachydanio rerio. DNA Cell. Biol. 11, 425-432.

SAMBROOK, J., FRITSCH, E.F., and MANIATIS, T. (1989). Molecular Cloning A Laboratory Manual, ed 2. (Cold Spring Harbor Laboratory Press, Cold Spring Harbor, New York.)

SANGER, F., NICKLEN, S., and COULSON, A.R. (1977). DNA sequencing with chain-terminating inhibitors. Proc. Natl. Acad. Sci. USA 74, 5463-5467.

SEKKALI, B., HELLEMANS, B.A., BELAYEW, A., MARTIAL, J.A., OLLEVIER, F., and VOLCKAERT, F.A. (1994). A comparative study of reporter gene activities in fish cells and embryos. Mol. Mar. Biol. Biotech. 3, 30-34.

SMITH, K.P., and SHARP, Z.D. (1991). A Pit-1 binding site $3^{\prime}$ to the transcription start site inhibits transcription elongation in vitro. Biochem. Biophys. Res. Commun. 177, 790-796.

SWEETING, R.M., and MCKEOWN, B.A. (1987). Growth hormone and seawater adaptation in Coho salmon, Oncorhynchus kisutch. Comp. Biochem. Physiol. 88A, 147-151.

SWENNEN, D., PONCELET, A.-C., SEKKALI, B., RENTIER-DELRUE, F., MARTIAL, J.A., and BELAYEW, A. (1992). Structure of the Tilapia (Oreochromis mossambicus) prolactin I gene. DNA 11, 673-684.

TANAKA, M., HOSOKAWA, Y., WATAHIKI, M., and NAKA-
SHIMA, K. (1992). Structure of the chicken growth hormone-encoding gene and its promoter region. Gene 112, 235-239.

TANG, Y., LIN, C.M., CHEN, T.T., KAWAUCHI, H., DUNHAM, R.A., and POWERS, D.A. (1993). Structure of the channel catfish (Ictalurus punctatus) growth hormone gene and its evolutionary implications. Mol. Mar. Biol. Biotechnol. 2, 198-206.

TASHJIAN, A.H., YASUMURA, Y., LEVINE, L., SATO, G.H., and PARKER, M.L. (1968). Establishment of clonal strains of rat pituitary tumor cells that secrete growth hormone. Endocrinology 82, 342-352.

THEILL, L.E., and KARIN, M. (1993). Transcriptional control of GH expression and anterior pituitary development. Endocr. Rev. 14, 670 689.

VIZE, P.D., and WELLS, J.R.E. (1987). Isolation and characterization of the porcine growth hormone gene. Gene 55, 339-344.

WESTERFIELD, M., WEGNER, J., JEGALIAN, B.G., DEROBERTIS, E.M., and PUSCHEL, A.W. (1992). Specific activation of mammalian Hox promoters in mosaic transgenic zebrafish. Genes Dev. 6, 591-598.

WILLIAMS, D.W., MULLER, F., LAVENDER, F.L., ORBAN, L., and MACLEAN, N. (1996). High transgene activity in the yolk syncytial layer affects quantitative transient expression assays in zebrafish embryos. Transgen. Res. 5, 451-458.

WRIGHT, J.M. (1989). Nucleotide sequence, genomic organization, and evolution of a major repetitive DNA family in tilapia (Oreochromis mossambicus/hornorum). Nucleic Acids Res. 17, 50715079.

YAMADA, S., HATA, J.I., and YAMASHITA, S. (1993). Molecular cloning of fish Pit-1 cDNA and its functional binding to promoter of gene expressed in the pituitary. J. Biol. Chem. 268, 24361-24366.

YOWE, D.L., and EPPING, R.J. (1995). Cloning of the barramundi growth hormone-encoding gene: a comparative analysis of higher and lower vertebrate GH genes. Gene 162, 255-259.

ZHU, Z., HE, L., and CHEN, T.T. (1992). Primary-structural and evolutionary analyses of the growth hormone gene from grass carp (Ctenopharyngodo $n$ idellus). Eur. J. Biochem. 207, 643-648.

Address reprint requests to: Dr. Joseph A. Martial Laboratoire de Biologie Moléculaire et de Génie Génétique Université de Liège Institut de Chimie B6 B-4000 Sart-Tilman, Belgium

Received for publication February 26, 1999; accepted in revised form March 10, 1999. 


\section{This article has been cited by:}

1. Eddie E. Deane, Norman Y. S. Woo. 2009. Modulation of fish growth hormone levels by salinity, temperature, pollutants and aquaculture related stress: a review. Reviews in Fish Biology and Fisheries 19:1, 97-120. [CrossRef]

2.R. Rajesh, K. C. Majumdar. 2008. The growth hormone-encoding gene isolated and characterized from Labeo rohita Hamilton is expressed in $\mathrm{CHO}$ cells under the control of constitutive promoters in 'autotransgene' constructs. Fish Physiology and Biochemistry 34:4, 413-436. [CrossRef]

3. R. Rajesh, K. C. Majumdar. 2007. A comparative account of the structure of the growth hormone encoding gene and genetic interrelationship in six species of the genus Labeo. Fish Physiology and Biochemistry 33:4, 311-333. [CrossRef]

4. Ricardo ALMULY, Yael POLEG-DANIN, Sergei GORSHKOV, Galina GORSHKOVA, Boris RAPOPORT, Morris SOLLER, Yechezkel KASHI, Bruria FUNKENSTEIN. 2005. Characterization of the 5 ' flanking region of the growth hormone gene of the marine teleost, gilthead sea bream Sparus aurata: analysis of a polymorphic microsatellite in the proximal promoter. Fisheries Science 71:3, 479-490. [CrossRef]

5. Katrin Hoffmann, Darcelle N. Dixon, Wayne K. Greene, Jette Ford, Ross Taplin, Ursula R. Kees. 2004. A microarray model system identifies potential new target genes of the proto-oncogeneHOX11. Genes, Chromosomes and Cancer 41:4, 309-320. [CrossRef] 